\title{
Development of a Conceptual Framework for Occupational Safety and Health in Palestinian Manufacturing Industries
}

\author{
Hanan S. Tuhul ${ }^{1}$, Amer El-Hamouz ${ }^{2, *(D)}$, A. Rasem Hasan ${ }^{3,4, *(D)}$ and Hanan A. Jafar ${ }^{3,4}$ (D) \\ 1 Hayara Consulting Engineering Office, P.O. Box 10, Tulkarm, Palestine; eng_h_tuhul@hotmail.com \\ 2 Chemical Engineering Department, An-Najah National University, P.O. Box 7, Nablus, Palestine \\ 3 Civil Engineering Department, An-Najah National University, P.O. Box 7, Nablus, Palestine; \\ h.jafar@najah.edu \\ 4 Research and Development Department, Water and Environmental Studies Institute, \\ An-Najah National University, P.O. Box 7, Nablus, Palestine \\ * Correspondence: elhamouz@najah.edu (A.E.-H.); mallah@najah.edu (A.R.H.)
}

Citation: Tuhul, H.S.; El-Hamouz, A.; Hasan, A.R.; Jafar, H.A. Development of a Conceptual Framework for Occupational Safety and Health in Palestinian Manufacturing Industries. Int. J. Environ. Res. Public Health 2021, 18, 1338. https://doi.org/10.3390/ ijerph18031338

Received: 19 December 2020

Accepted: 27 January 2021

Published: 2 February 2021

Publisher's Note: MDPI stays neutral with regard to jurisdictional claims in published maps and institutional affiliations.

Copyright: (c) 2021 by the authors. Licensee MDPI, Basel, Switzerland. This article is an open access article distributed under the terms and conditions of the Creative Commons Attribution (CC BY) license (https:// creativecommons.org/licenses/by/ $4.0 /)$.

\begin{abstract}
The annual increase in the number of occupational accidents and diseases in the Palestinian manufacturing industries confirms a serious problem that threatens the Occupational Safety and Health (OSH) in such industries, with negative consequences in the society and economy. As the Palestinian OSH data are insufficient, tightwad, and with discrepancies in published data by different agencies, this study aimed to investigate the OSH status in the Palestinian manufacturing industries and determine the Palestinian OSH trends rates based on international practice in the EU and USA. Also, to shed light on the OSH situation in the manufacturing sector and warrant the inspection and monitoring of industries by the respective officials. The OSH data of 175 industrial establishments and 199 industrial employees was collected by meetings, interviews, and structured questionnaires for the period 2009-2016. The US and EU OSHA (Occupational Safety and Health Administration) formulas were used to calculate the OSH rates. The analysis showed that $32.30 \%$ of the industrial employees suffered from occupational injuries. The average injury rate was 7566 per 100,000 workers, indicating a low OSH level in the Palestinian manufacturing industries. The leather industry was found as the most dangerous in terms of $\mathrm{OSH}$, with an average safety performance factor (SPF) of 145.6 off days/accident. Pearson's chi-square test $(\chi 2)$ revealed a correlation between occupational accidents and injuries and the employees' commitment and lost working days. An OSH framework was developed based on safety and sustainable development pillars to assure effective enforcement of the $\mathrm{OSH}$ law and prevent future occupational accidents and diseases.
\end{abstract}

Keywords: conceptual framework; Occupational Safety and Health; occupational accidents; occupational injuries; $\mathrm{OSH}$ rates; frequency severity index; safety performance factor; syndicates

\section{Introduction}

Despite the increasing interest in Occupational Safety and Health (OSH), about 6300 deaths and 860,000 nonfatal occupational injuries are recorded daily worldwide [1-7]. Apart from threatening the life and health of workers [8-11], workplace accidents are highly sound economic sense $[12,13]$. Businesses spend $\$ 170$ billion/year on costs associated with occupational injuries and illnesses [14,15], and about $4.0 \%$ of the world's Gross Domestic Product (GDP) is swallowed up by the direct and indirect costs of occupational accidents and diseases $[16,17]$.

Human behavior and the industry nature are significant drivers for the occurrence and re-occurrence of occupational accidents [18-20]. While there have been substantial reductions in accidents resulting from technological failures, industrial accidents due to human error have significantly increased, representing a contribution of up to $80 \%$ [21,22]. However, this increase in the percentage might be attributed to the rate-reducing other causes $[23,24]$, and thus warrant investigations. 
Accurate statistics and figures on the number of occupational accidents or fatalities in the Middle East (ME) are minimal $[25,26]$, specifically in the manufacturing, mining, and construction industries [27-30]. For instance, Gulf Cooperation Countries (GCC) have a large expatriate population whose majority originate from India, Pakistan, Nepal, and other Asian countries suffer from occupational accidents [31,32]. For the past few years, labor advocacy groups in Qatar have raised concerns about the increasing numbers of deaths and disabilities resulting from work-related injuries [33].

In Palestine, the occupational accidents (OA) statistics are published by the Ministry of Labor $(\mathrm{MoL})$ and the Ministry of Health $(\mathrm{MoH})$ through their annual reports and documented as well by the Palestinian insurance companies (PICs) and the General Federation of Palestinian Trade Unions (GFPTU) [34,35]. Of particular interest among different OA types are the accidents occurred in the Palestinian manufacturing industries, hereafter called the manufacturing accidents (MA).

The updated total OA statistics in Palestine with all subcategories are given in Table 1 [36], where the manufacturing sector is the largest contributor to these statistics. The MoL and other governmental and non-governmental institutions in Palestine try to improve the OSH conditions inside facilities, mainly for the manufacturing industries [37-39], due to their higher workforce and impact on the Palestinian economy, among other sectors [38].

Table 1. The main Occupational Safety and Health (OSH) statistics between the years 2009 and 2016 according to the Ministry of Labor (MoL).

\begin{tabular}{ccccccc}
\hline & All O.A & M.A & P.D & O.F & O.D & OWD \\
\hline 2009 & 444 & 270 & 46 & 9 & 1 & 105 \\
2010 & 549 & 234 & 54 & 14 & 2 & 107 \\
2011 & 399 & 175 & 31 & 13 & 3 & 96 \\
2012 & 715 & 268 & 64 & 12 & NA & NA \\
2013 & 752 & 269 & 20 & 20 & NA & NA \\
2014 & 650 & 278 & 79 & 12 & 1 & 245 \\
2015 & 664 & 260 & 35 & 21 & NA & 138 \\
2016 & 682 & 233 & 20 & 15 & NA & NA \\
2017 & 496 & 227 & 23 & 7 & NA & 320 \\
2018 & 561 & 312 & 20 & NA & NA & 290 \\
\hline Total & 5224 & 2122 & 368 & 119 & 7 & 862 \\
\hline
\end{tabular}

Note: O.A = Occupational Accidents, M.A = Manufacturing Accidents, P.D = Permanent Disabilities, O.F = Occupational Fatalities, O.D = Occupational Diseases, OWD = Out of Work Days, NA = No clear statistics have been received in the reports.

The high number of occupational injuries and illnesses documented by the Palestinian labor law (PLL) indicate the Palestinian manufacturing industries' critical situation and the crucial need for OSH measures [40].

Previous studies such as Al Habeel and Aiesh, 2012, Mohammed, 2014, and Abu Zeiter, 2018 [41-43] presented the OSH procedures in general, while others such as $\mathrm{Al}$ Moghny, 2006, and Salem, 2009 [44,45] discussed the OSH in the manufacturing sector in Gaza strip and Tulkarm city respectively, but without development of any system, model, or framework to solve the related safety problems. Recently, two studies $[39,46]$ by the international labor organization (ILO) were conducted on several Palestinian workplaces and concluded the need to study the OSH problem and work-related accidents from different aspects, like non-compliance with laws, lack of emphasis on sanctions, and the absence of essential laws and regulations, to understand their causes and develop preventative measures to mitigate their dangerous consequences.

According to the United States Agency for International Development (USAID) and the Palestinian Federation of Industries (PFI) [47], the Palestinian industrial sectors employ about $13.0 \%$ of the total workforce and contribute $16.0 \%$ to the GDP. These sectors constitute $57.1 \%$ of the whole manufacturing sector in the 11 governorates of the West Bank (WB) part of Palestine. They include more than $57.0 \%$ of the workforce [48], which endorses 
the need to highlight OSH conditions in these sectors. In this context, the presented study aimed to investigate the Palestinian OSH trends and associated rates for the Palestinian manufacturing sector's industrial establishments. Additionally, this research aimed to develop an OSH framework that governs the OSH situation in Palestine.

\section{Materials and Methods}

\subsection{Data Collection and Sample}

This research has targeted eight Palestinian industrial sectors with a significant weight in the Palestinian economy: metal and aluminum, paper and cartoon, leather and shoes, food and beverages, chemical, wood and furniture, and plastic industries.

The targeted industries in this research are characterized as statistically heterogeneous populations due to their differences in size, the number of employees, and contribution to the GDP. There was a need to determine the sample size (number of establishments) per each industrial sector and in each governorate to have a representative sample. The stratified multistage sampling technique and Thompson Formula $[49,50]$ were used to determine the sample size. In such a method, the whole heterogeneous population can be divided into smaller groups concerning the study's characteristics. Also, it allows for three or more stages of sampling units, which was required for this research [51,52].

Accidents' data with consequences were collected from the MoL and MoH's annual reports and collected directly from PICs and GFPTU. Meetings and interviews were held with the OSH stakeholders to explore their opinions concerning the OSH and discuss their cooperative role in the improvement process. Additionally, two structured questionnaires were developed and reviewed by experts from the academia: the workplace questionnaire was administered to the establishments' owners or managers, hereafter called employers as well, and the employees' questionnaire was administered to the establishments' employees.

Out of the total 8948 registered industrial establishments in Palestine, 265 establishments were categorized under the 8 targeted manufacturing sectors and located in the West Bank (WB) 11 governorates, and 175 establishments responded to the workplace questionnaire. Later, a more representative sample of 102 industrial establishments was considered for further statistical analysis. Some of the industries either closed their business or changed their activities during the period of concern.

In terms of the selected establishments' employees, 199 employees were selected and interviewed.

\subsection{Data Analysis}

\subsubsection{Thematic Analysis Approach}

Seven semi-structured interviews were conducted with officials from six different OSH stakeholders (MoL, Civil Defense (CD), Palestinian Insurance Federation (PIF), PICs, Palestinian Capital Market Authority (PCMA), and General Federation of Palestinian Trade Unions (PGFTU)) to investigate the OSH status in the Palestinian industrial sector. According to Braun and Clarke [53], interviews were transcribed and analyzed using the thematic analysis approach.

\subsubsection{Statistical Analysis}

The quantitative data from the questionnaires were analyzed using Statistical Package for Social Sciences, IBM SPSS Statistics for Windows, Version 26.0 (IBMD Corp., Armonk, NY, USA), to illustrate the collected data, and test for possible correlations between the number of occupational accidents and both the human effect and the nature of industry.

\subsubsection{OSHA Rate Formulas}

The US and EU OSHA formulas were used to calculate the OSH rates (Table 2). 
Table 2. The applied OSH rate formulas and their definitions.

\begin{tabular}{|c|c|c|c|}
\hline OSH Rate & Symbol & Definition & Reference \\
\hline \multicolumn{4}{|c|}{ US-OSHA Rates (based on $200,000 \mathrm{~h}$ of worker exposure to a hazard) } \\
\hline Incident Rate & $\begin{array}{l}\text { IR1 } \\
\text { IR2 }\end{array}$ & $\begin{array}{l}\text { Number of occupational injuries and/or illnesses or } \\
\text { lost workdays per } 100 \text { full-time employees. }\end{array}$ & [54] \\
\hline Fatal Accident Rate & FAR & $\begin{array}{c}\text { Number of fatalities based on } 1000 \text { employees } \\
\text { working their entire lifetime or } 10^{8} \text { working hours } \\
\text { over total hours worked by all employees during the } \\
\text { period covered }\end{array}$ & [54] \\
\hline Lost Time Case Rate & LTC & $\begin{array}{c}\text { Number of lost time cases } \times 200,000 \text { over the number } \\
\text { of employees' labor hour worked days. }\end{array}$ & [55] \\
\hline Severity Rate & SR & $\begin{array}{c}\text { Total number of lost workdays by the total number of } \\
\text { recordable incidents. }\end{array}$ & [57] \\
\hline \multicolumn{4}{|c|}{ EU-OSHA Rates (based on 100,000 workers exposed to risk employees) } \\
\hline Fatality Rate & FR & Number of fatalities expected per person per year. & [56] \\
\hline Workplace Injury Rate & IR & $\begin{array}{l}\text { Number of workplace injuries of the total number of } \\
\text { employees per 100,000 employed persons. }\end{array}$ & {$[57,58]$} \\
\hline Accident Frequency Rate & AFR & $\begin{array}{l}\text { Number of workplace accidents reported per number } \\
\text { of human-hours worked } \times 1,000,000\end{array}$ & {$[57,58]$} \\
\hline Accident Severity Rate & ASR & $\begin{array}{l}\text { Number of reported human-days lost } \times \\
1,000,000 / \text { number of human-hours worked. }\end{array}$ & {$[57,58]$} \\
\hline $\begin{array}{l}\text { Occupational Disease } \\
\text { Incidents Rate }\end{array}$ & ODIR & $\begin{array}{c}\text { Number of workplace diseases of the total number of } \\
\text { employees per 100,000 employed persons. }\end{array}$ & [57] \\
\hline \multicolumn{4}{|c|}{ Severity Indicators } \\
\hline Safety Performance Factor & SPF & $\begin{array}{l}\text { Number of working hours/days lost due to each } \\
\text { occupational accident, regardless of its severity. }\end{array}$ & [58] \\
\hline Frequency Severity Index & FSI & $\begin{array}{l}\text { A combined formula for both AFR and ASR that gives } \\
\text { a combined effect of accidents/injuries happened and } \\
\text { the corresponding working days lost. }\end{array}$ & [56] \\
\hline
\end{tabular}

US-OSHA Formulas:

1. OSHA Incident Rate based on injuries and illnesses (IR1) [54]:

$$
I R 1=\frac{\text { Number of injuries and illnesses }}{\text { Totally worked labor hours }} \times 200,000
$$

2. OSHA Incident Rate based on lost workdays (IR2) [54]:

$$
I R 2=\frac{\text { Number of lost workdays }}{\text { Totally worked labor hours }} \times 200,000
$$

3. Fatal Accident Rate (FAR) [54]:

$$
F A R=\frac{\text { Number of Fatalities }}{\text { Totally worked labor hours }} \times 10^{8}
$$

4. Lost Time Case Rate (LTC) [55]:

$$
L T C=\frac{\text { Number of lost Time cases }}{\text { Totally worked labor hours }} \times 200,000
$$


5. Severity Rate (SR) [56]:

$$
S R=\frac{\text { Total number of lost workdays }}{\text { Total number of recordable incidents }}
$$

EU-OSHA Formulas:

1. Fatality Rate (FR) [54]:

$$
\mathrm{FR}=\frac{\text { Number of Fatalities per Year }}{\text { Total number of Employees }}
$$

2. Workplace Injury Rate (IR) [57]:

$$
I R=\frac{\text { Number of Fatal \& Non }- \text { Fatal injuries }}{\text { Total number of Employees }} \times 100,000
$$

3. Accident Frequency Rate (AFR) [57]:

$$
\text { AFR }=\frac{\text { Number of workplace accidents }}{\text { Totally worked labor hours }} \times 1000,000
$$

4. Accident Severity Rate (ASR) [57]:

$$
\text { ASR }=\frac{\text { Number of workdays lost to accidents }}{\text { Totally worked labor hours }} \times 1000,000
$$

5. Occupational Disease Incidents Rate (ODIR) [57]:

$$
\text { ODIR }=\frac{\text { Number of occupational diseases cases }}{\text { Total number of Employees }} \times 100,000
$$

In both formulas, the Total Worked Labor Hours (TWLH) was calculated depending on the information and equations below:

Total Worked labor Hours [54]:

$$
\text { TWLH }=\mathrm{H} \times \mathrm{D} \times \mathrm{E}
$$

where $(\mathrm{H})$ is the number of working hours per day $=8 \mathrm{~h} /$ day,

(D) is number of working days per year $=276$ Days / year,

(E) is the total number of employees $=2208 \mathrm{~h} /$ year.

In addition, the SPF was calculated based on Reference [58]:

$$
\mathrm{SPF}=\frac{\text { Total working hours lost }}{\text { Total number of incidents }}
$$

and the Frequency Severity Index (SFI) was calculated according to Reference [56]:

$$
\mathrm{FSI}=\frac{\sqrt{(A F R \times A S R)}}{1000}
$$

The severity and performance indices were applied to determine the most severe industrial sector.

\subsubsection{OSH Correlation}

Pearson's chi-squared test $\left(\chi^{2}\right)$ with a significance level $(\alpha) \leq 0.05$ was applied to find the correlations between occupational accidents/injuries and the different OSH variables relative to the industrial establishments and their employees from one side, and the effect of both the human factor and the industry nature from the other side. Based on the 
study results, an OSH framework that governs the OSH situation is to be developed and consulted with stakeholders.

\section{Results}

\subsection{Collected Data and Interviews' Analyses}

A tremendous discrepancy has been noticed between the occupational accidents statistics documented by the Ministry of Labor $(\mathrm{MoL})$ and those reported by the Palestinian insurance companies (PICs) [34,35], with the documented cases by the PICs being of 5 to 6 times higher than those published by the MoL (Figures 1 and 2). There is a need to more precisely determine the associated OSH rates as a first step for the sustainable development of the industrial sector in Palestine.

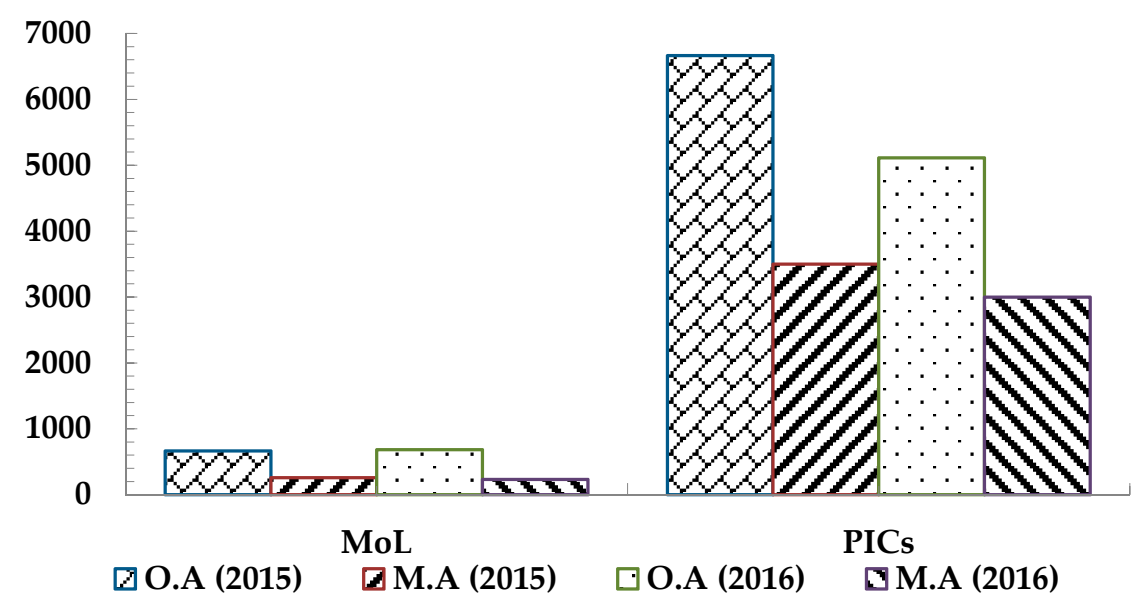

Figure 1. Number of manufacturing accidents and the total occupational accidents according to the Ministry of Labor (MoL) and the Palestinian insurance companies (PICs) reports (2015/2016), where O.A = Occupational Accidents, M.A = Manufacturing Accidents.

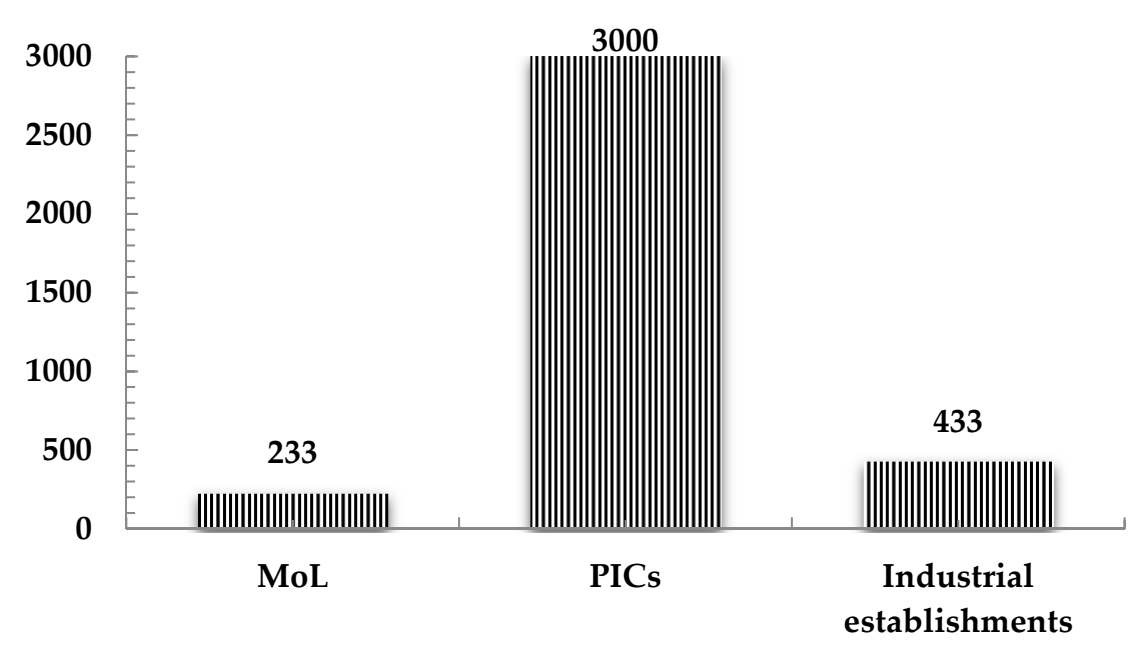

Figure 2. The number of occupational accidents (O.A) according to the Ministry of Labor (MoL) and Palestinian insurance companies (PICs) (2016-2017) reports [35-40], and those obtained from the industrial establishments during this research's survey.

The interviews' analysis and the developed central themes are shown in Figure 3. The interviewees uncovered two contradictory groups of factors (Figure 4): the first group contains the obstacles that impede the development of the OSH in the industrial sector, while the other clarifies the most influential factors needed during the OSH development process. 


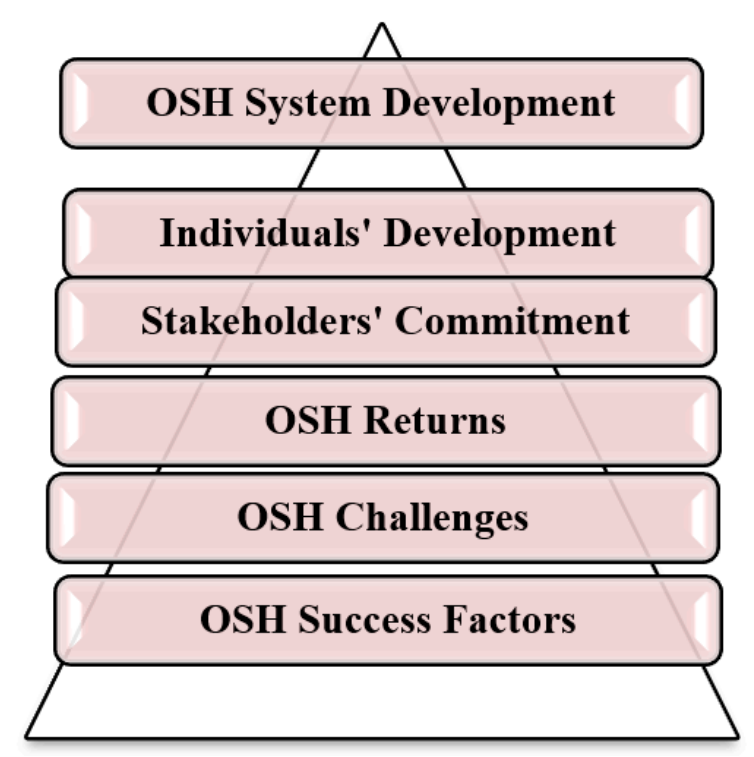

Figure 3. The central themes developed based on the conducted interviews.

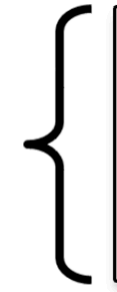

- Culture Nature

- Educational Level

- Suitable Regulations

- Law Enforcement

-Financial \& Political Barriers

Success Factors $\begin{cases}\cdot \text { Facing the Problem } \\ \bullet \text { Priority } \\ \bullet \text { Commitment \& Cooperation } \\ \bullet \text { Good Efforts Orientation } \\ \cdot \text { Continuous Evaluation }\end{cases}$

Figure 4. The obstacles and influences in the OSH development process.

\subsection{Questionnaires'Analysis}

\subsubsection{Survey Population}

Workplace Survey

About $41.0 \%$ of the responding establishments were established after the official enforcement of the PLL. Metal industries were at the top of the respondents' list with 23.3\%. In terms of educational qualification, $54.9 \%$ of the respondents have bachelor's degrees and more, while $29.5 \%$ have secondary certificates or less.

Employees' Survey

The majority of employees were males, with $93.9 \%$ of the employees' questionnaire respondents. Youths have a strong presence in this sector as $59.1 \%$ of the respondents were less than 30 years old. Regarding the working experience, $41.5 \%$ of the respondents had an estimated working experience of 5 years or less.

\subsubsection{OSH Requirements and Tools}

Table 3 shows the recent percentages of the Basic Health and Safety Requirements (BHSR) availability in industrial establishments. 
Table 3. The estimated percentages of the availability of the Basic Health and Safety Requirements (BHSR) in the industrial establishments according to the 2018 workplace questionnaire analysis.

\begin{tabular}{lcc}
\hline \multirow{2}{*}{ BHSR } & \multicolumn{2}{c}{$\mathbf{2 0 1 8}$} \\
\cline { 2 - 3 } & Workplace & Employees \\
\hline Fire extinguishing means & $68.0 \%$ & $85.1 \%$ \\
First aid tools & $97.7 \%$ & $94.9 \%$ \\
Emergency exits & $82.8 \%$ & $77.6 \%$ \\
Awareness and guidance & $73.0 \%$ & $83.0 \%$ \\
Primary medical examinations & $32.4 \%$ & $33.5 \%$ \\
Periodic medical & $31.4 \%$ & $25.8 \%$ \\
examinations & $85.3 \%$ & $90.4 \%$ * \\
Reporting accidents & $95.1 \%$ & $92.9 \%$ \\
Workers insurance & & \\
\hline
\end{tabular}

* This percentage refers to the employees' knowledge about reporting accidents and the entity they should report the accident to, not for the number of reported accidents.

The analysis showed an obvious variation in OSH tools' availability in industrial establishments, as illustrated in Figure 5.

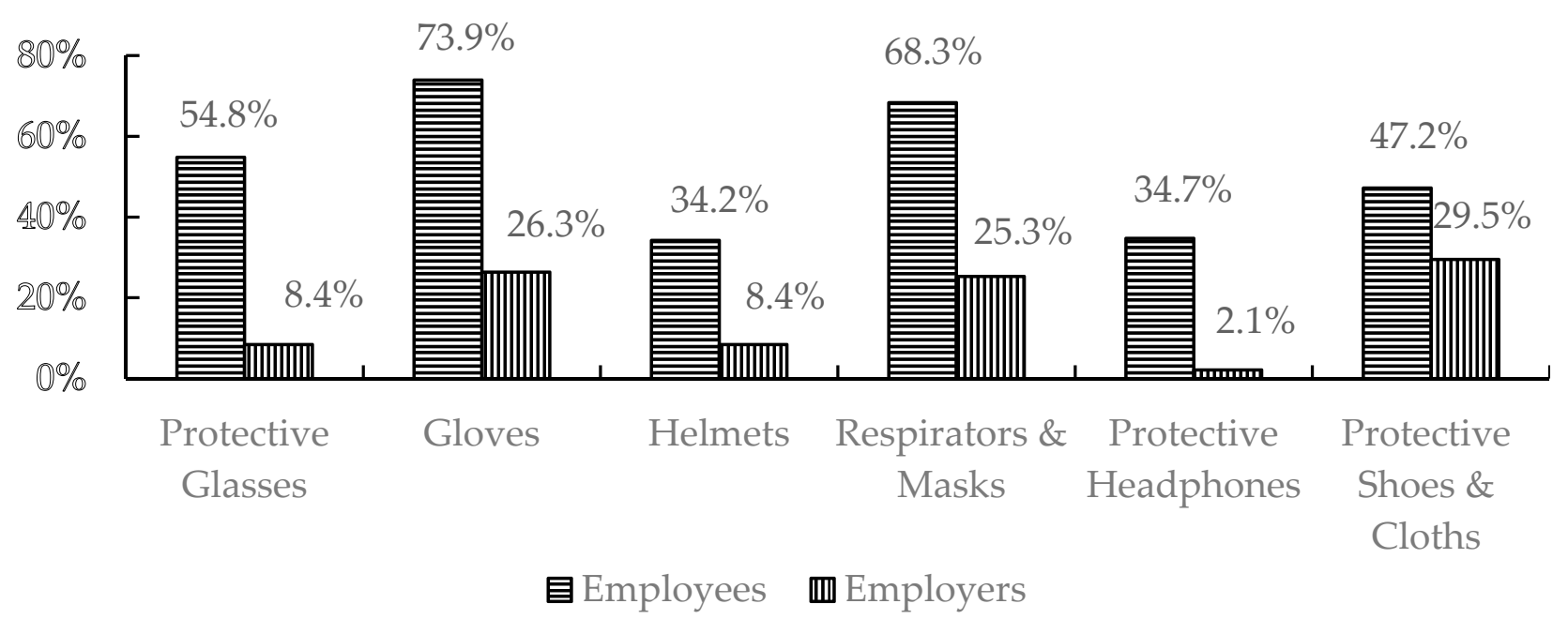

Figure 5. Percentages of OSH tools' existence according to both employees' and workplace survey analysis.

\subsubsection{Exposure to Risk}

Regarding the OSH in industrial sectors, about 2913 industrial employees were exposed to occupational risks, $35.0 \%$ were under 26 years old. Furthermore, $69.6 \%$ of the exposed employees had secondary education certificates or less, while $10.4 \%$ were completely illiterate. About $15.0 \%$ of these employees had 12 months or less work experience.

In terms of employment contracts, $45.1 \%$ of the exposed employees' contracts were temporary contracts. Besides, $40.0 \%$ of the exposed employees' contracts were not officially documented. The highest percentages of exposed employees were reported in the plastic sector with $28.0 \%$, while the lowest rate was in the leather industrial sector with $4.0 \%$.

\subsubsection{Occupational Accidents and Diseases}

During 2017, about $81.0 \%$ of the industrial establishments experienced at least one occupational accident case. The highest reported percentage was in the industrial food sector, where $32.3 \%$ of the employees suffered from occupational injuries. A considerable annual upward trend has been noticed during 2009-2016 in occupational accidents, injuries, fatalities, and diseases (Figure 6). 


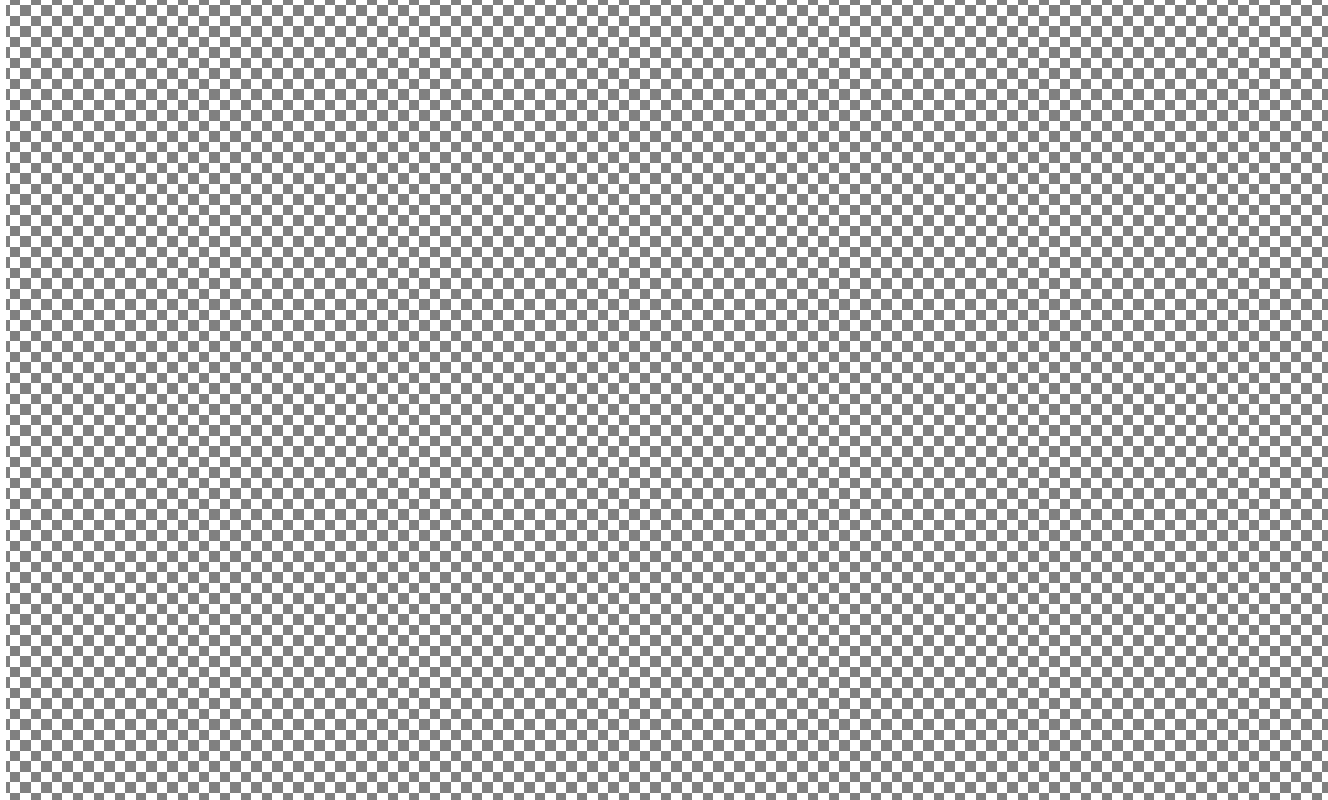

Figure 6. The OSH statistics in the industrial sectors between the years 2009 and 2016. Where: O.I = Occupational Injuries, O.A: Occupational Accidents, Occupational Diseases, and O.F: Occupational Fatalities.

Related to occupational diseases, $32.4-33.5 \%$ of the employees had preliminary examinations, and $25.8-31.4 \%$ had periodic inspections. Approximately $9.1 \%$ of the industrial employees suffered from chronic occupational diseases. According to employees, the highest occupational diseases' percentage was recorded in metal industries, whereas from employers' perspective, the highest rate was reported in food industries (Figure 7). About $49.4 \%$ of the industrial establishments at the workplace level had at least one occupational disease case during 2017.

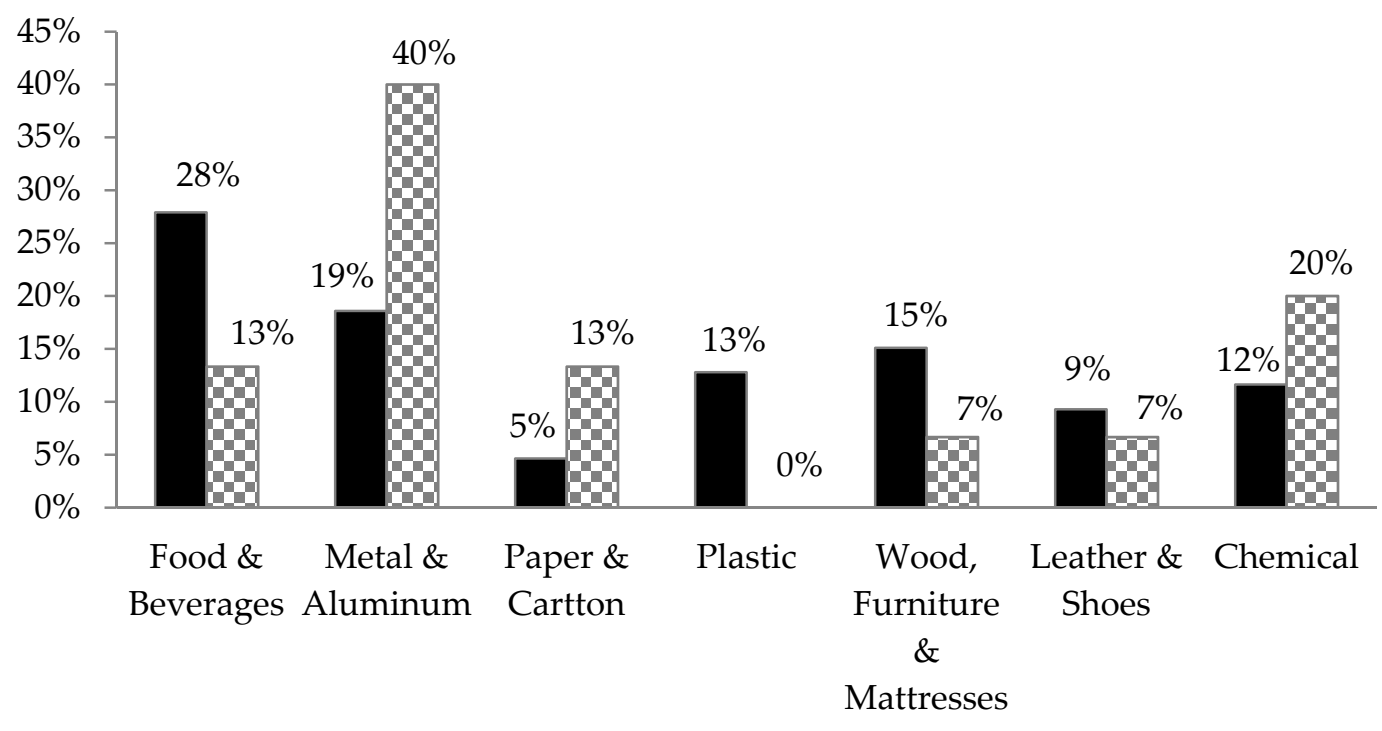

Establishments $\because$ Employees

Figure 7. The occupational diseases' percentages per industrial sector according to the employees and their employers.

From employees' perspective, the most common occupational disease was joints disease $(53.3 \%)$, while employers reported that joints diseases and respiratory problems were the most common (Figure 8). 


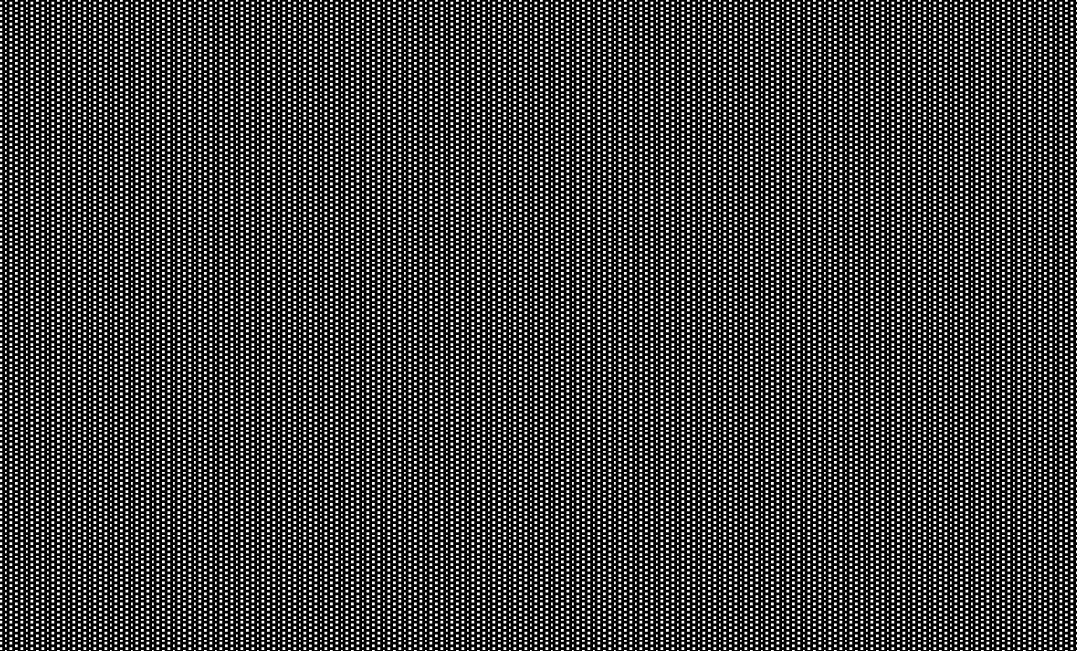

Figure 8. The percentages of the types of the occupational disease in the industrial sectors for the employees and the employers.

\subsubsection{Accidents' Causes}

The results showed that most employers and employees refer to the causes of the recurrence of occupational accidents to the carelessness of the employees. However, $36.8 \%$ of the employers think that the non-use of the OSH personal tools was the main reason.

\subsubsection{Lost Working Days}

Due to these occupational accidents in the manufacturing sector, the absence average was 60.2 days/accident. The highest average of lost working days due to accidents was in metal and aluminum industries, with an average of 146.5 days/accident, whereas the lowest average was recorded in leather and shoe industries (14.3 days/accident).

\subsubsection{Financial Losses}

The industrial establishments have incurred substantial financial losses, with the highest losses in employees' compensations (Figure 9).

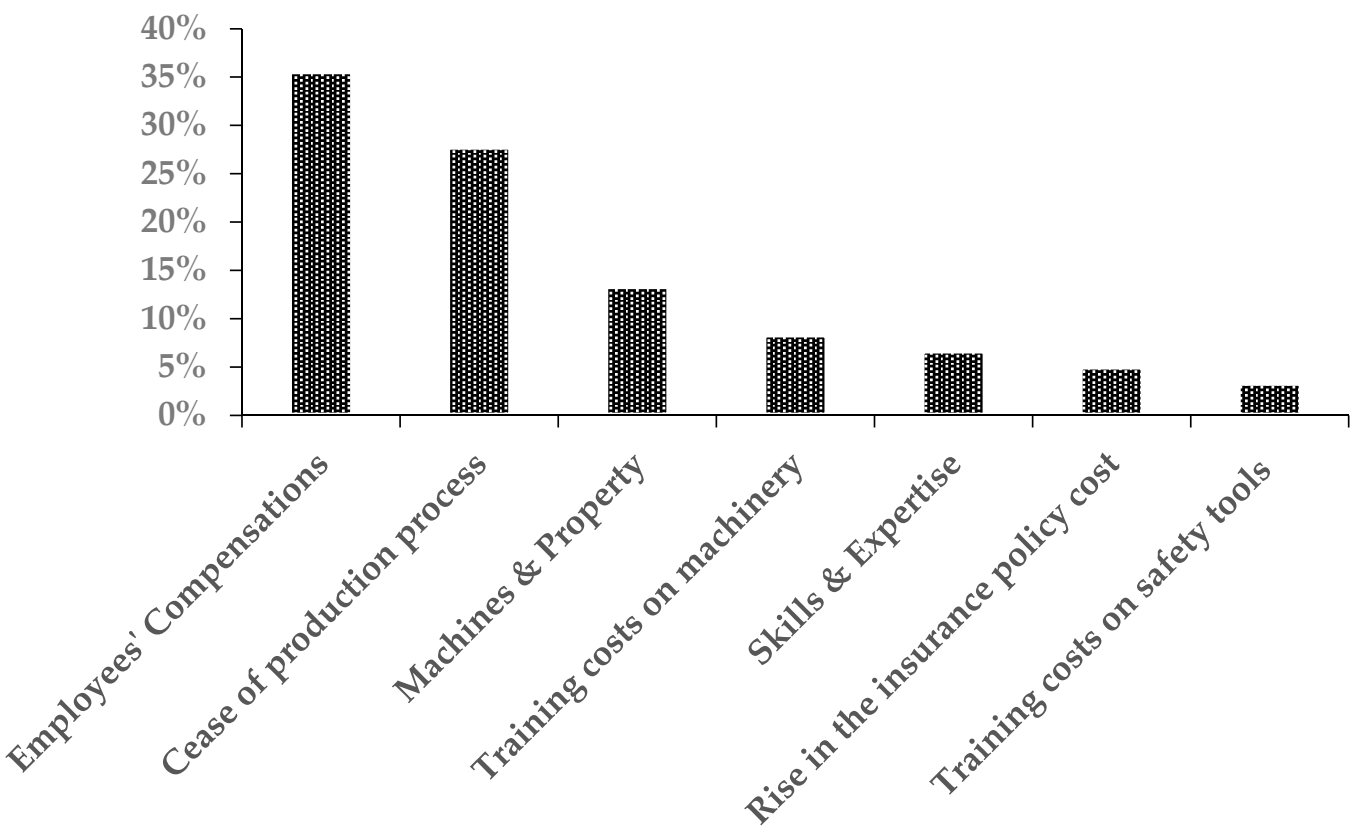

Figure 9. The percentages of the industrial establishments' losses due to occupational accidents. 


\subsubsection{External Investigation}

The workplace results revealed that competent official OSH bodies investigated $89.9 \%$ of the industrial establishments. Table 4 shows the official entities responsible for these investigation processes according to employers' and employees' answers.

Table 4. Percentage of participating inspectors in the questionnaire from different official entities in charge of OSH inspection in Palestine.

\begin{tabular}{lcc}
\hline & Employers & Employees \\
\hline Ministry of Labor & $29.5 \%$ & $25.1 \%$ \\
Ministry of Health & $13.0 \%$ & $17.7 \%$ \\
Civil Defense & $46.7 \%$ & $30.2 \%$ \\
Ministry of National Economy & $2.2 \%$ & $14.3 \%$ \\
Ministry of Environment & $1.4 \%$ & $12.7 \%$ \\
Others & $7.2 \%$ & $0.0 \%$ \\
\hline
\end{tabular}

\subsubsection{Environmental Considerations}

According to the workplace survey, $73.3 \%$ of the industrial establishments produce industrial wastes. The primary industrial wastes disposal method was waste dumps, followed by recycling and selling (Figure 10).

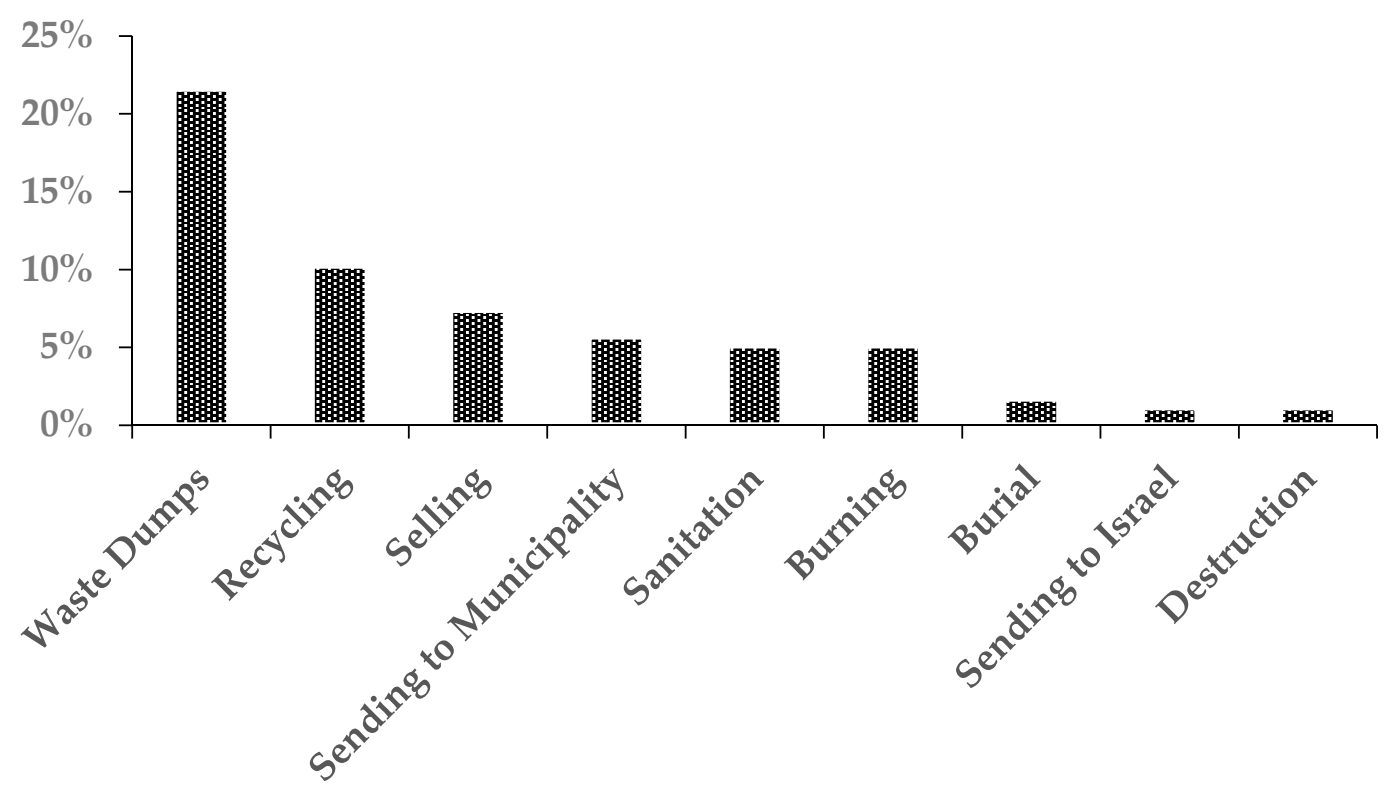

Figure 10. Percentages of industrial waste disposal methods.

\subsection{OSH Trends and Rates in the Palestinian Manufacturing Sector}

The total number of documented work-related injuries has fluctuated during 20092016, as shown in Table 5.

Table 5. Number of injuries by manufacturing industries as reported by the Ministry of Labor $(\mathrm{MoL})$ and the Palestinian insurance companies (PICs) during the target years.

\begin{tabular}{cccccccccc}
\hline & $\mathbf{2 0 0 9}$ & $\mathbf{2 0 1 0}$ & $\mathbf{2 0 1 1}$ & $\mathbf{2 0 1 2}$ & $\mathbf{2 0 1 3}$ & $\mathbf{2 0 1 4}$ & $\mathbf{2 0 1 5}$ & $\mathbf{2 0 1 6}$ & $\mathbf{2 0 1 7}$ \\
\hline MoL & 270 & 234 & 175 & 268 & 269 & 278 & 259 & 232 & 135 \\
PICs & NA & NA & +1900 & +2000 & NA & NA & 3500 & 3000 & NA \\
\hline
\end{tabular}

${ }^{*}$ First Half of the Year. Note: NA = no data is available. 
The metal and plastic industries sectors witnessed the highest number of occupational accidents among the manufacturing industries in Palestine (Figure 11), which is in line with other national and international studies [59-61].

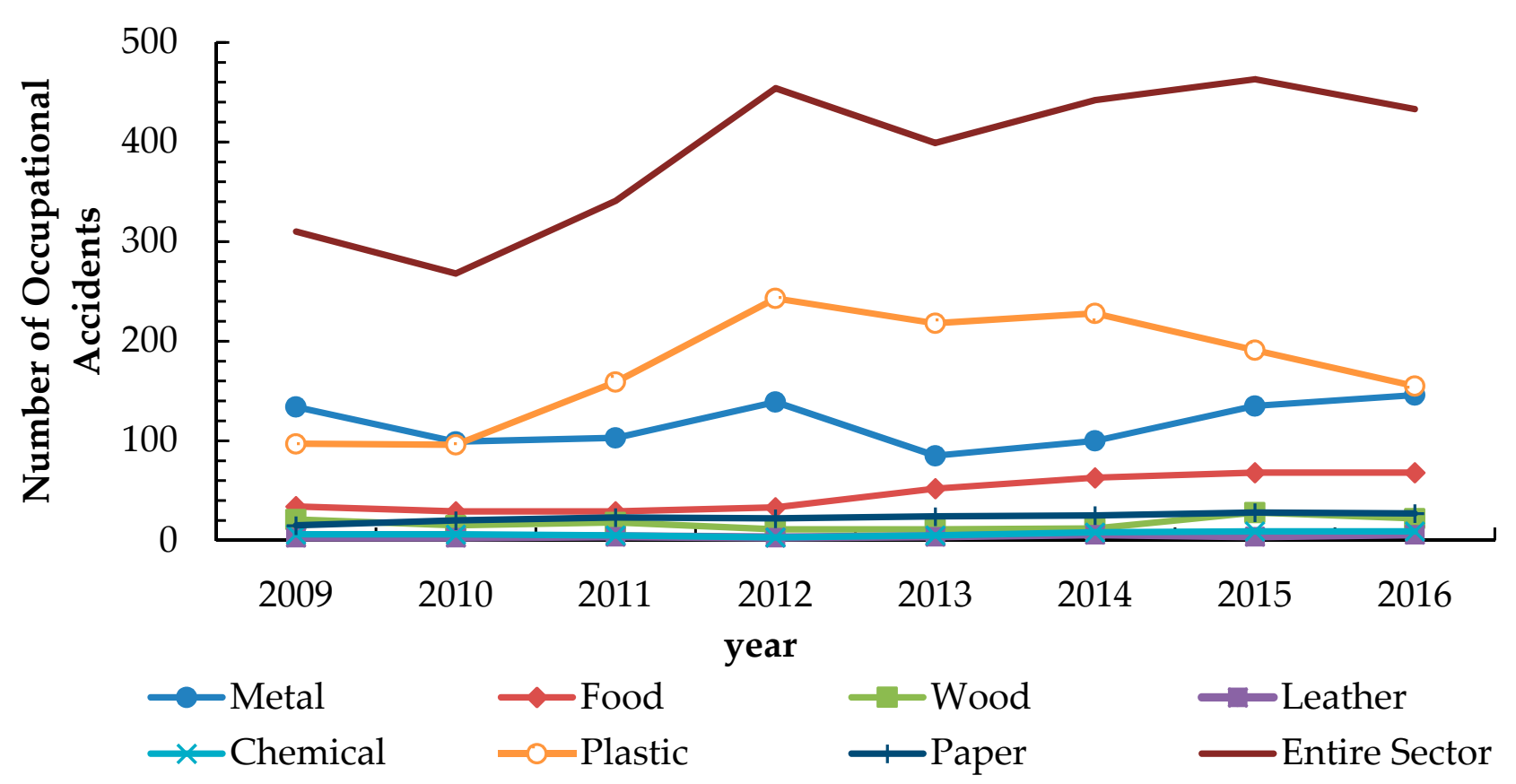

Figure 11. Occupational accidents in all Palestinian industrial sectors during 2009-2016.

A summary of the OSH statistics and estimated financial losses of each industrial sector under study is shown in Table 6.

Table 6. The OSH statistics of each industrial sector between the years 2009 and 2016.

\begin{tabular}{lccccccc}
\hline \multicolumn{1}{c}{ Industrial Sector } & Fixed Employees & O. A & O. I & O. F & O. D & $\begin{array}{c}\text { LWH } \\
\text { (days) }\end{array}$ & $\begin{array}{c}\text { Estimated Losses } \\
\text { (US\$) }\end{array}$ \\
\hline Leather and Shoes Industries & 2445 & 33 & 31 & 0 & 8 & 555 & 10,045 \\
\hline Plastic Industries & 6649 & 1387 & 583 & 1 & 3 & 1664 & 6600 \\
\hline Paper and Cartoon Industries & 1989 & 184 & 186 & 0 & 3 & 521 & 49,150 \\
\hline Chemical Industries & 1737 & 51 & 46 & 0 & 11 & 194 & 1850 \\
\hline Wood and Furniture Industries & 2266 & 138 & 109 & 0 & 0 & 907 & 137,800 \\
\hline Food and beverages Industries & 6669 & 376 & 262 & 2 & 26 & 2041 & 50,190 \\
\hline $\begin{array}{l}\text { Aluminium and } \\
\text { Metallurgical Industries }\end{array}$ & 6273 & 941 & 896 & 1 & 1 & 3002 & 66,020 \\
\hline Entire Industrial Sector & 28,028 & 3110 & 2113 & 4 & 52 & 8884 & 321,655 \\
\hline
\end{tabular}

Note: O. A = Occupational Accidents; O. I = Occupational Injuries; O. F = Occupational Fatalities; O. D = Occupational Diseases; LWH $=$ Lost Working Hours.

Based on data presented in Table 6, the US/EU OSHA rates were calculated and summarized in Tables 7 and 8. It is concluded from these data that around $68.0 \%$ of accidents ended in injuries and/or deaths. 
Table 7. Calculated US-OSHA rates for each industrial sector and the entire industrial sector for the period 2009-2016.

\begin{tabular}{cccccc}
\hline Industrial Sector & IR1 & IR2 & FAR & LTC & SR \\
\hline Leather and Shoes Industries & 1.5 & 20.3 & 0.0 & 1.4 & 13.2 \\
Plastic Industries & 18.8 & 21.1 & 6.4 & 8.0 & 1.2 \\
Paper and Cartoon Industries & 8.5 & 24.4 & 0.0 & 8.5 & 2.9 \\
Chemical Industries & 3.2 & 9.0 & 0.0 & 2.2 & 3.3 \\
Wood and Furniture Industries & 7.5 & 50.5 & 0.0 & 5.8 & 6.9 \\
Food and beverages Industries & 5.3 & 26.1 & 10.4 & 3.7 & 4.7 \\
Aluminium andMetallurgical Industries & 13.7 & 42.8 & 6.5 & 13.0 & 3.2 \\
Entire Industrial Sector & 10.3 & 28.1 & 5.4 & 7.1 & 2.8
\end{tabular}

Note: IR1 = OSHA Incident Rate (based on injuries and illnesses); IR2 = OSHA Incident Rate (based on lost workdays); FAR = Fatality Accidents Rates; LTC = Lost Time Case Rate; SR = Severity Rate.

Table 8. Calculated EU-OSHA rates for each industrial sector and the entire industrial sector for 2009-2016.

\begin{tabular}{cccccc}
\hline Industrial Sector & IR & FR & AFR & ASR & ODIR \\
\hline Leather and Shoes Industries & 1271.9 & 0.0 & 6.1 & 101.5 & 320.9 \\
Plastic Industries & 8820.4 & $1.40 \times 10^{-4}$ & 94.1 & 105.8 & 39.4 \\
Paper and Cartoon Industries & 9329.1 & 0.0 & 41.9 & 122.2 & 127.5 \\
Chemical Industries & 2646.0 & 0.0 & 13.2 & 44.9 & 572.2 \\
Wood and Furniture Industries & 6640.3 & 0.0 & 37.3 & 252.7 & 0.0 \\
Food and beverages Industries & 3799.3 & $2.30 \times 10^{-4}$ & 24.9 & 130.3 & 348.4 \\
Aluminium and & $14,418.8$ & $1.43 \times 10^{-4}$ & 68.3 & 214.0 & 14.3 \\
Metallurgical Industries & 7656.0 & $1.18 \times 10^{-4}$ & 50.6 & 140.4 & 169.9
\end{tabular}

Note: IR $=$ Number of workplace injuries of the total number of employees per 100,000 employed persons, FR $=$ Number of fatalities expected per person per year; AFR $=$ Number of workplace accidents reported per number of human-hours worked $\times 1,000,000$; ASR $=$ Number of reported human-days lost $\times 1,000,000 /$ number of human-hours worked; ODIR $=$ Number of workplace diseases of the total number of employees per 100,000 employed persons.

\subsection{Incident and Fatality Accident Rates}

The average number of days lost per each occupational injury/disease is 2.8 days, and for every 100 full-time employees (Table 7), 10.3 workers are involved in occupational accidents/diseases compared to 20 and 3.5 for Ireland and the USA, respectively $[62,63]$.

Plastic and metal industries are of the most dangerous sectors due to their high IR1 and IR2. In the chemical and leather sectors, for every 100 full-time employees, about $86.4 \%$ and $95.4 \%$ of employees respectively, suffer lost time due to occupational injury/disease. This is in line with UK results presented by the UK Health and Safety Executive (HSE) [64].

The average IR value presented in Table 8 and Figure 12 rings an alarm for Palestine's severe safety situation compared to other countries' IR values.

\subsection{Occupational Incident and Accident Frequency Rates}

The ODIR values showed an increasing trend behavior, while IR values were slightly decreasingly fluctuating and eventually decreased to around 6200 (Figure 13). On the other hand, the AFR values were nearly constant over the study period, whereas ASR doubled over the same period (Figure 14). 


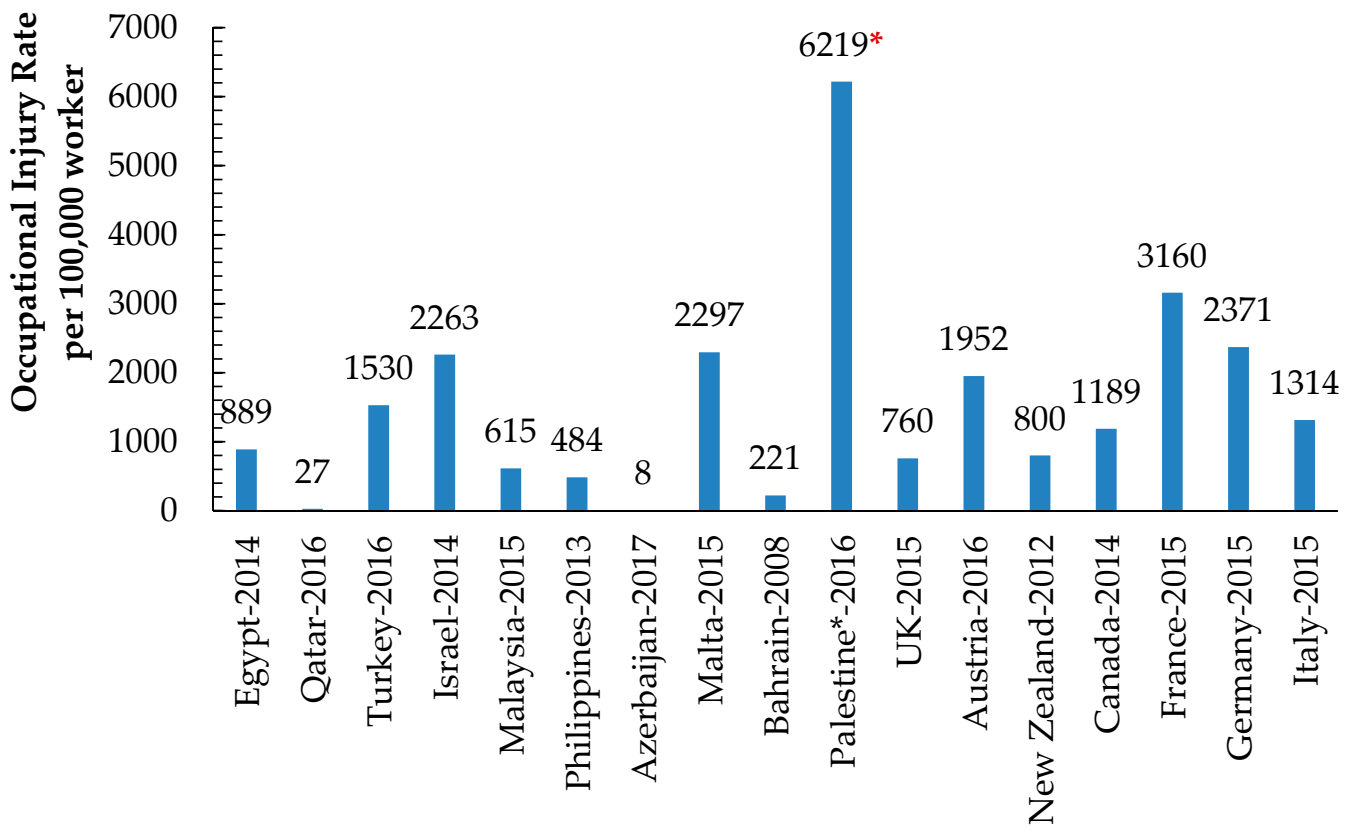

Figure 12. The Occupational Injury Rate (per 100,000 workers) in Palestinian manufacturing industries compared to those of other international countries. * The Calculated IR of 2016 obtained OSH statistics for the Palestinian industrial establishments.

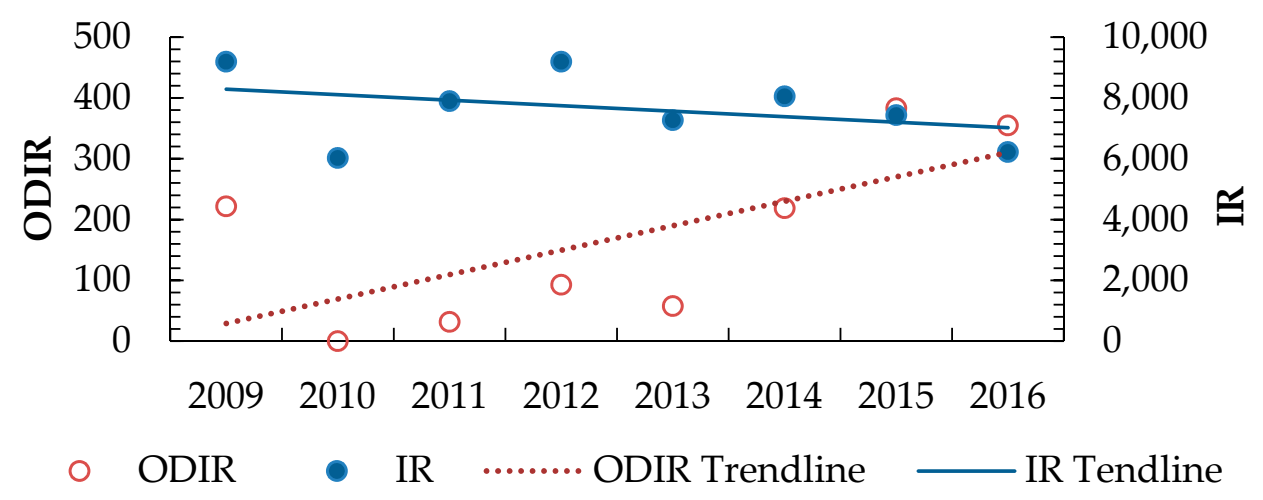

Figure 13. ODIR and IR of the industrial sectors during 2009-2016. Where ODIR = Number of workplace diseases of the total number of employees per 100,000 employed persons, IR = Number of workplace injuries of the total number of employees per 100,000 employed persons.

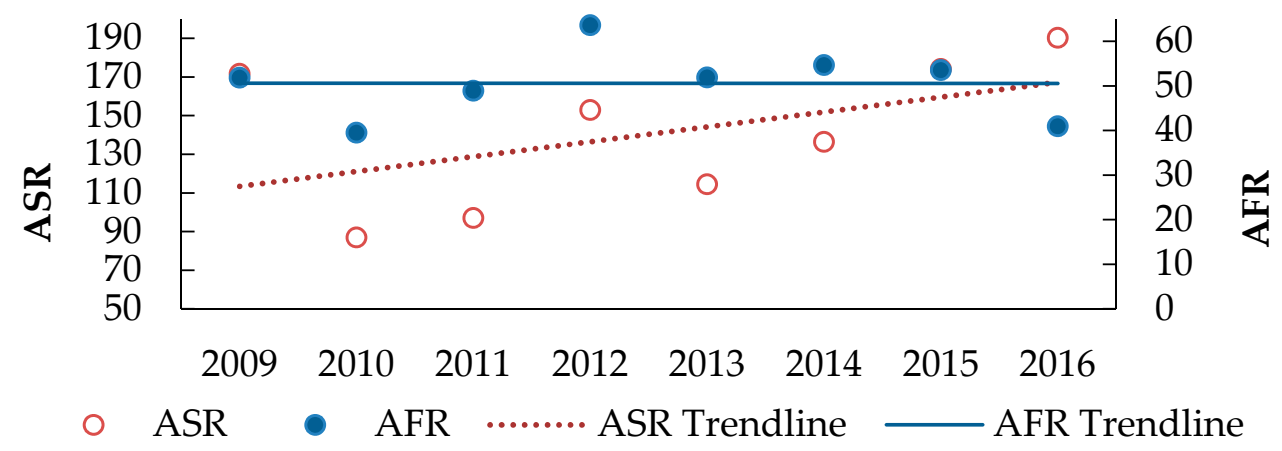

Figure 14. ASR and AFR Rates of the industrial sectors during 2009-2016. Where ASR = Number of reported human-days lost $\times 1,000,000 /$ number of human-hours worked, AFR $=$ Number of workplace accidents reported per number of human-hours worked $\times 1,000,000$. 
A more in-depth investigation of the calculated injury rates based on US-OSHA equation rates for each industrial sector is shown in Figure 15, and in accordance with Lagerstrom et al., 2019, and Yanar et al., 2019, on the danger of both the metal and wooden industries all over the world [24,65]. The industrial food sector has the highest number of occupational diseases, the second-highest number of occupational accidents, and the highest number of occupational fatalities during the scoping period, leading to a tangible value of IR1 above the average IR1. Metal and wood industries have an IR1 value above average, but after years it declines (Figure 15). These results show that the decreasing trend of IR1 values does not mean that the workplace is safe, as ODIR shows the opposite behavior.
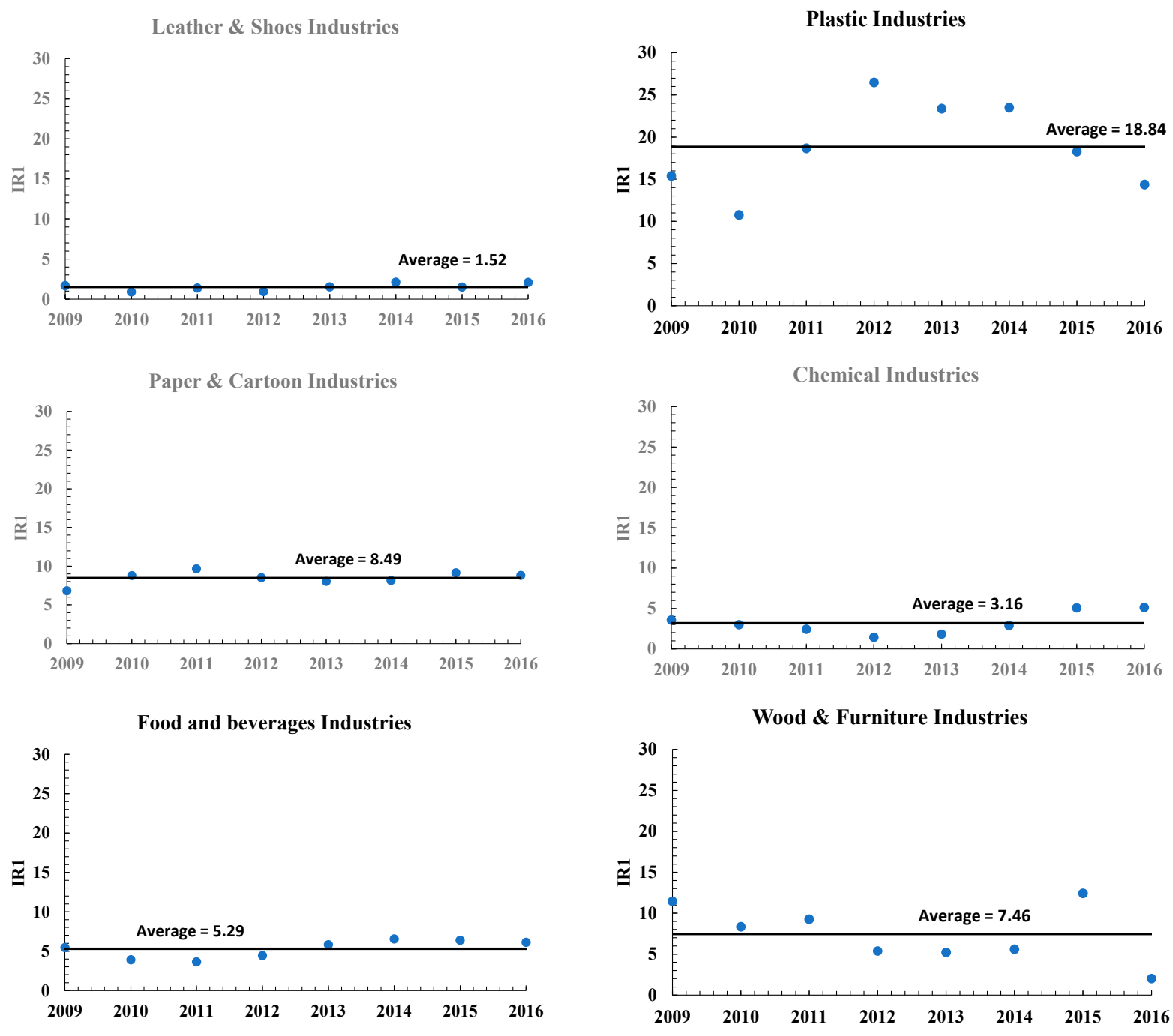

Aluminum \&Metallurgical Industries
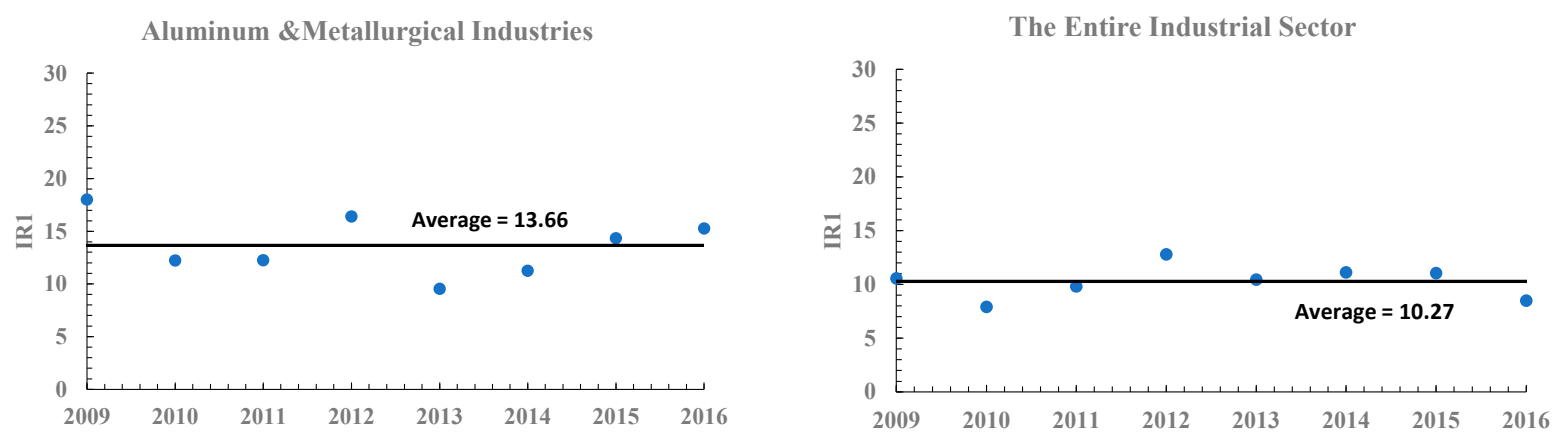

Figure 15. The Occupational Safety and Health Administration (OSHA) Incident Rate, based on injuries and illnesses (IR1) rates (per 100 full-time workers) for each targeted industrial sector during 2009-2016. 


\subsection{Frequency Severity Index and Safety Performance Factor}

Due to the limited availability of workplace-related safety data, frequency severity index (FSI) and SPF were calculated based on work time lost due to occupational incidents during 2009-2016.

Metal industries had the highest average FSI of 3.79, while chemical industries had the lowest average FSI value of 0.54 (Figure 16). Figure 17 shows the FSI values of the entire industrial sector over the period 2009-2016.

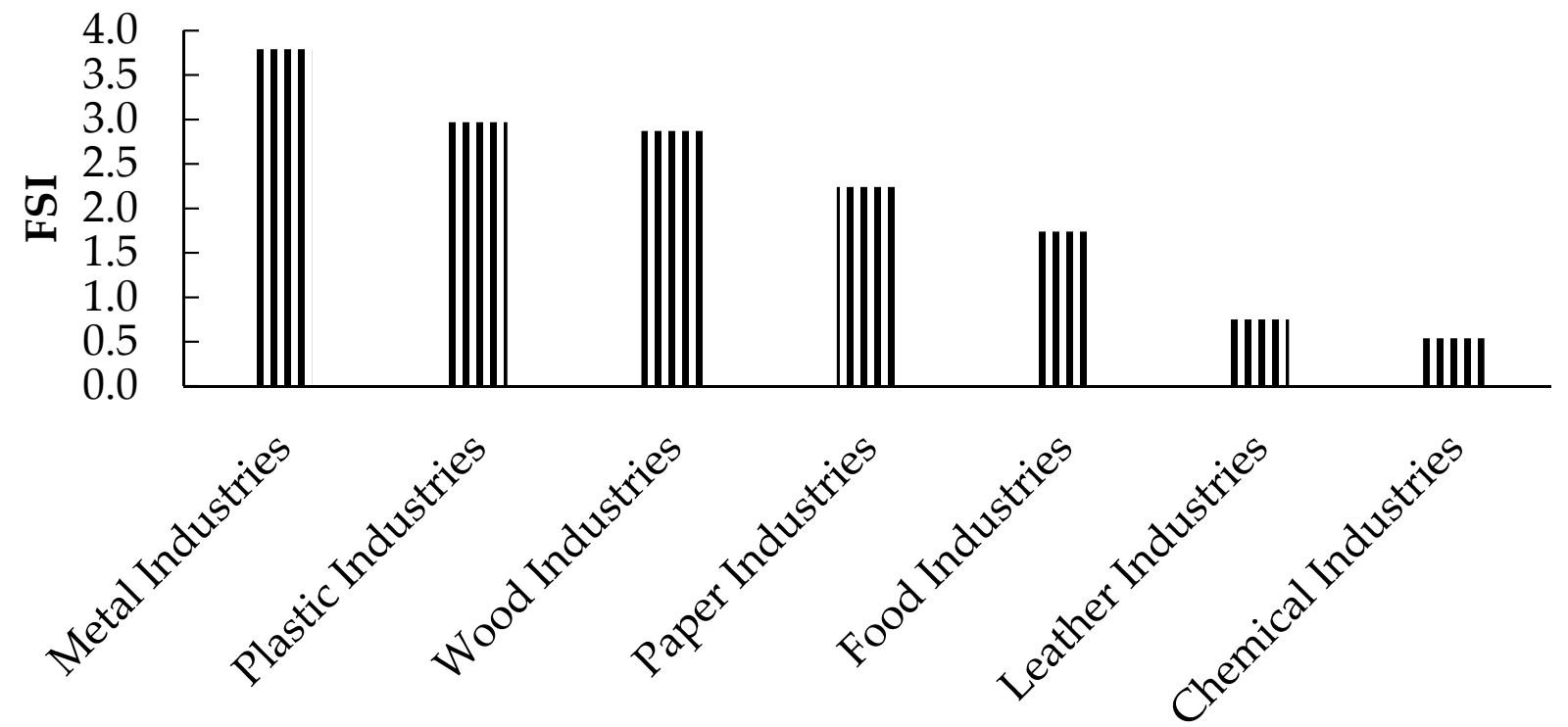

II FSI Average

Figure 16. The severity classification of the Palestinian industrial sectors according to the FSI indicator.

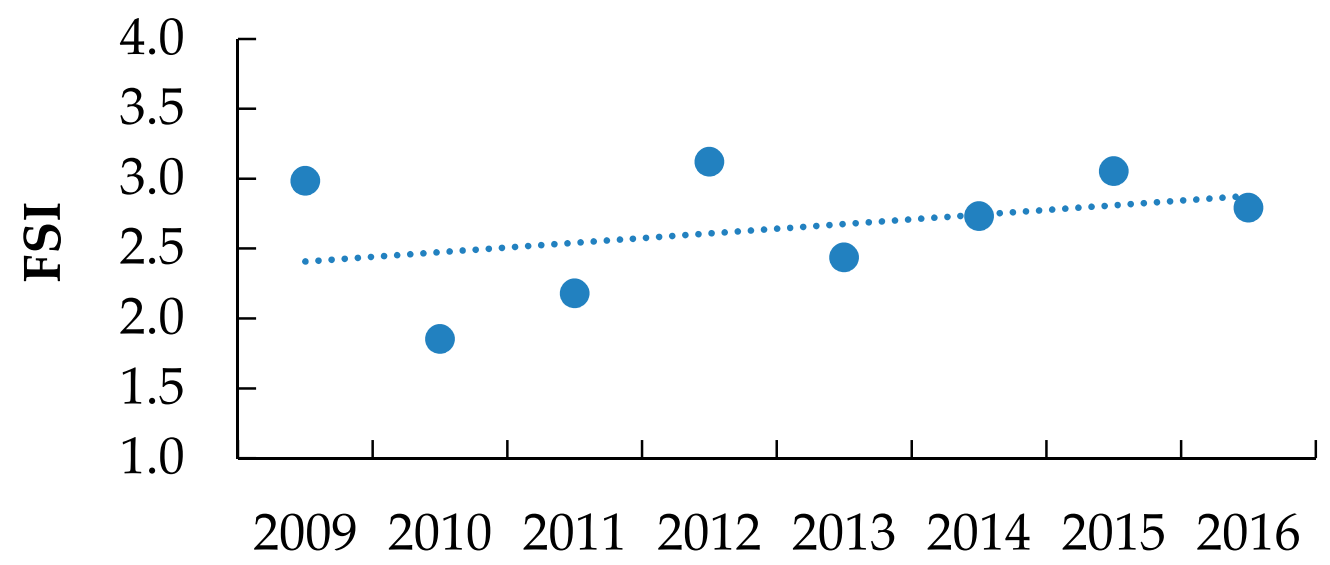

Figure 17. The severity classification of the Palestinian industrial sectors according to the FSI indicator during 2009-2016.

The increasing trend in the SPF indicator (Figure 18) sheds light on the industrial manufacturing sector's severity. Leather industries had the highest number of lost working days, with an average SPF of 145.6 working days lost/occupational accident. On the other hand, plastic industries had the lowest average SPF of 9.8, although it has the second highest FSI. 


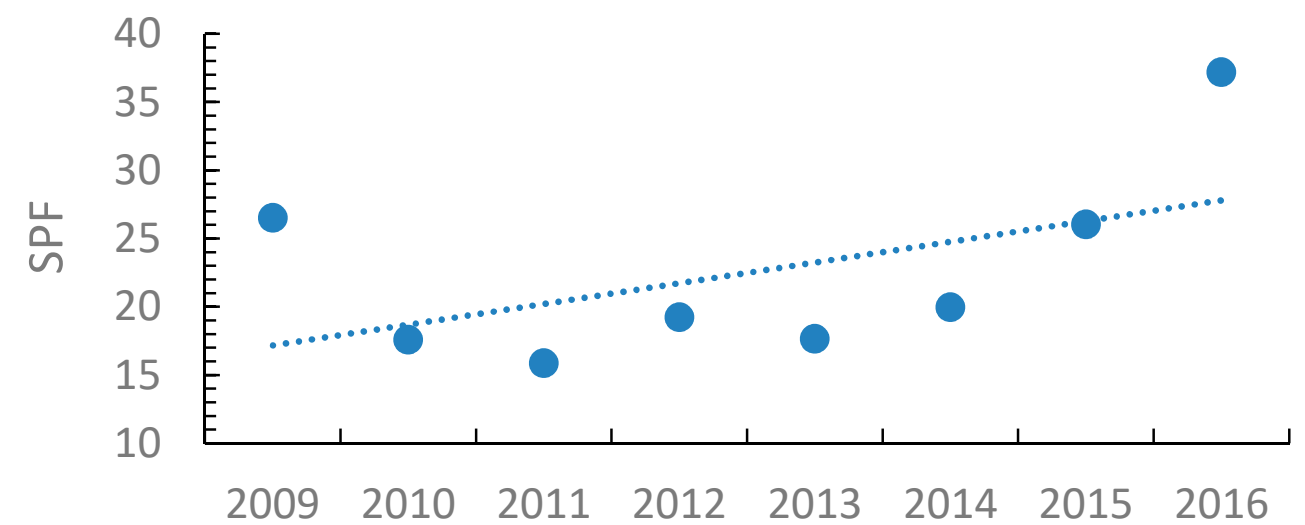

Figure 18. The SPF indicators for the Palestinian industrial sector between the years 2009 and 2016, where SPF = Number of working hours/days lost due to each occupational accident, regardless of its severity.

Figure 19 classifies the Palestinian industrial sectors according to their seriousness, starting with the sector with the highest SPF and ending with the lowest SPF. The figure also shows the classification variations once FSI is used as a comparison indicator.

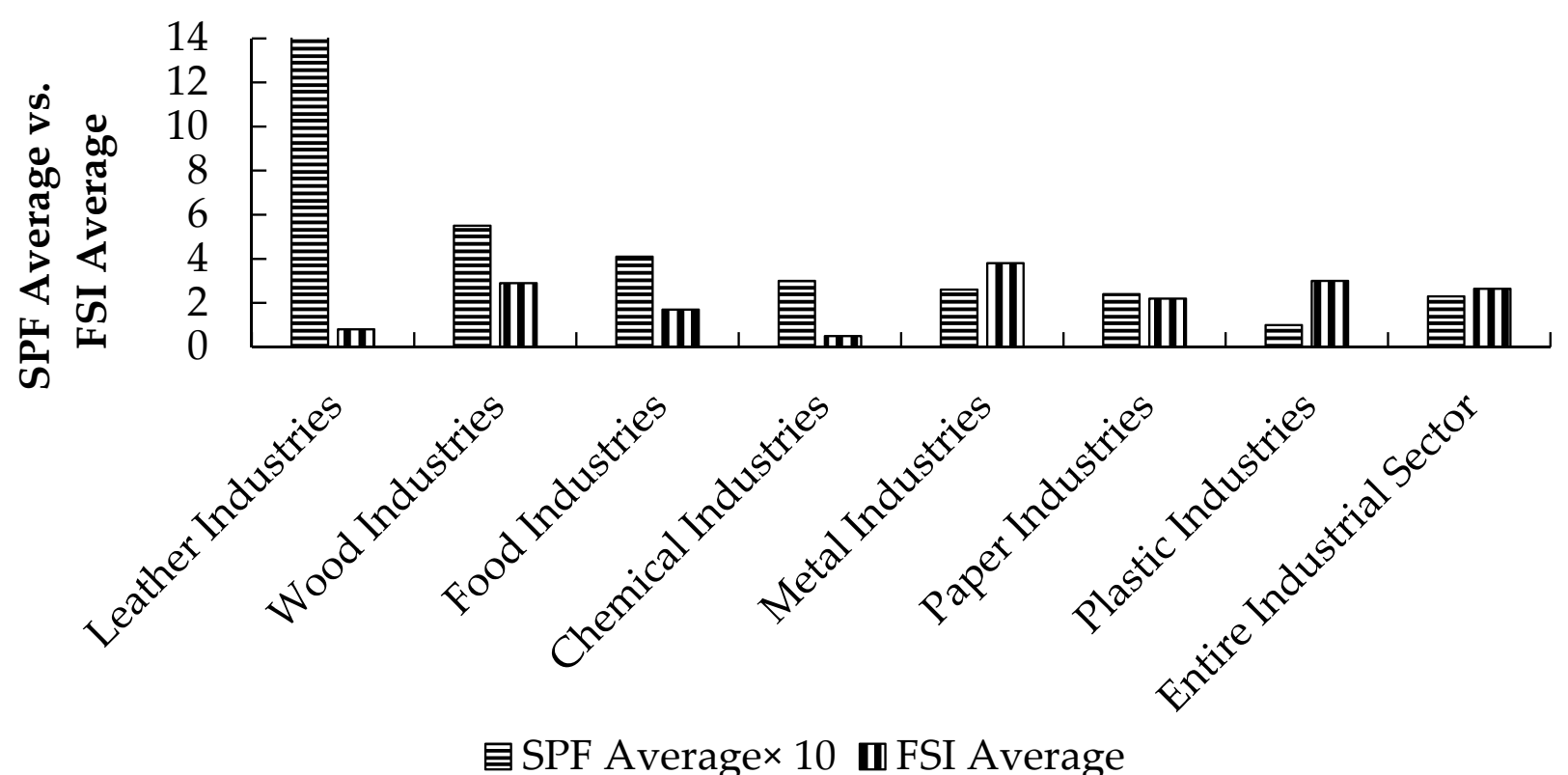

Figure 19. Severity classification of the Palestinian industrial sectors according to SPF and FSI indicators.

\subsection{OSH Correlations}

The correlation hypotheses for all cases are illustrated in Appendix A. Case correlation (1) confirmed that while providing OSH requirements and developing OSH strategies affect occupational disease occurrences only, the employees' commitment follow-up has its apparent effects on the numbers of the occurring occupational accidents/injuries/diseases. Simultaneously, these occupational accidents/injuries and diseases impact the number of lost working days/hours (Figure 20). According to case correlation (2), wherever the industrial establishments are, or to what sector they belong, this does not affect their orientation or attitudes towards their industries, employees, and all the OSH issues (Figure 21). 

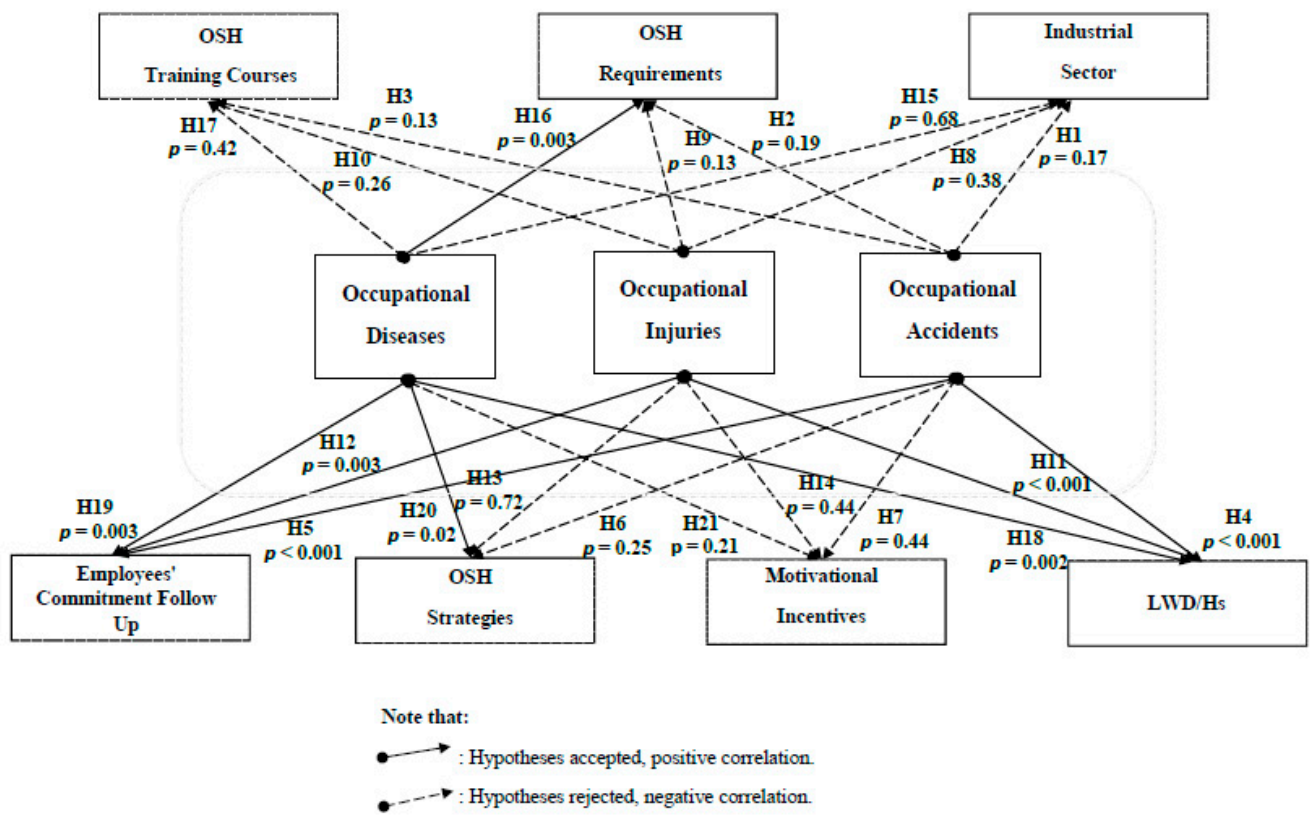

Figure 20. The presentation of case correlation (1) and its hypothesis testing. LWD/h is the loss of working days or hours.

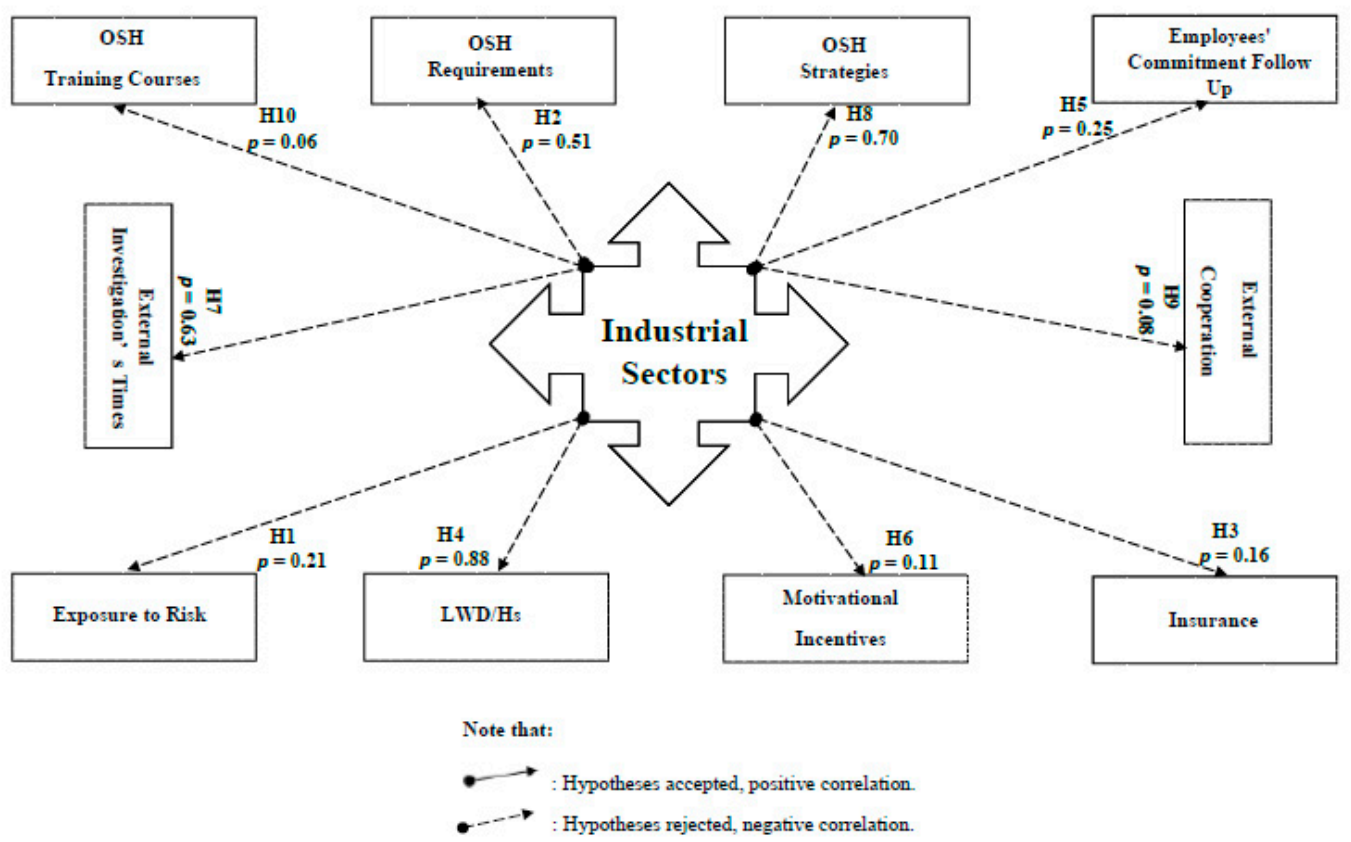

Figure 21. The presentation of case correlation (2) and its hypothesis testing.

Case correlation (3) is another illustration of correlations between the OSH variables. The correlation revealed that employees of ages 21-25 years old were the most prone to occupational injuries, while those of ages 26-30 years old were the most likely to suffer from occupational diseases.

While age was the only independent variable that correlates with employees' injuries, employees' diseases were affected by other variables. The analysis showed that employees with more than 10 years of experience were suffering from occupational diseases (Figure 22). 


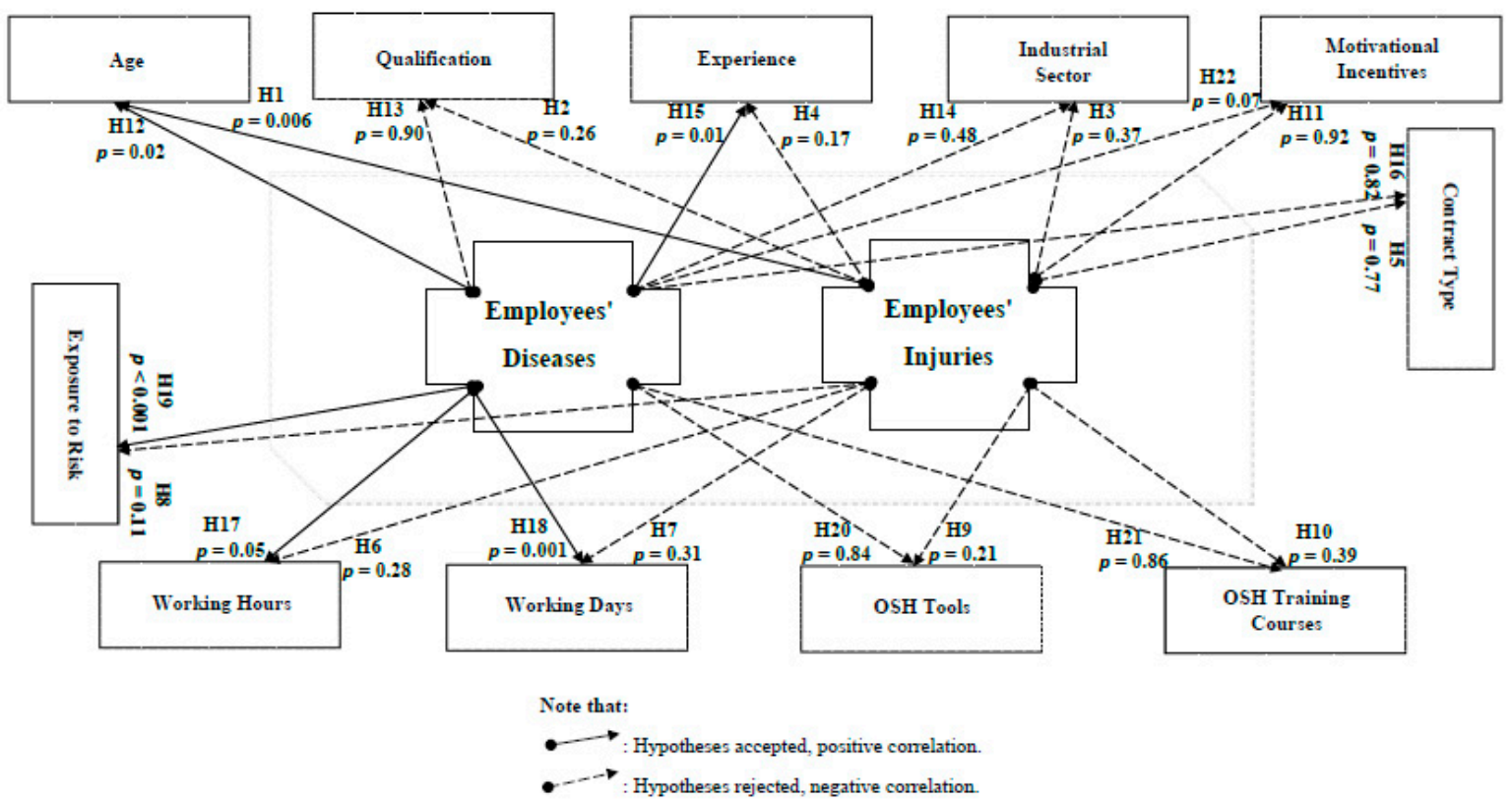

Figure 22. The presentation of case correlation (3) and its hypothesis testing.

In terms of occupational diseases, the problem seems to be much more complicated. There is a non-existent correlation according to case (4) between the primary and periodic medical examinations, that are considered the most essential and necessary OSH requirement, and the occupational diseases mainly originate due to the failure to conduct these examinations as one of the Labor Law (PLL) violations (Figure 23).

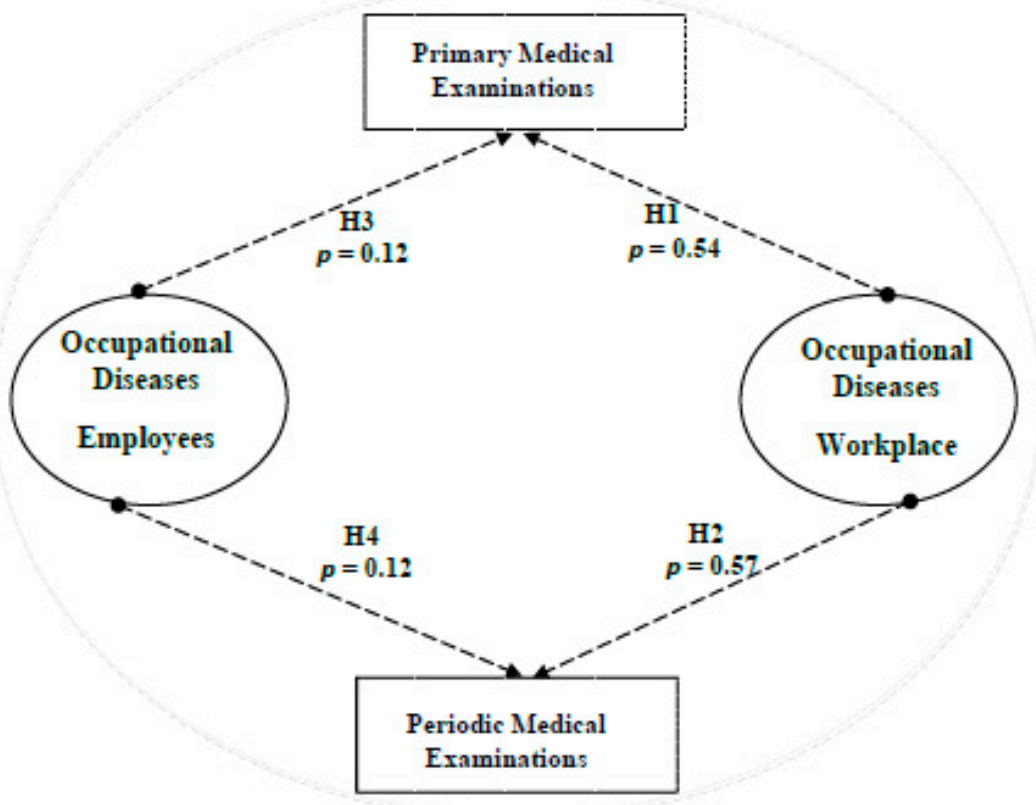

Note that:

$\rightarrow$ : Hypotheses accepted, positive correlation.

: Hypotheses rejected, negative correlation.

Figure 23. The presentation of case correlation (4) and its hypothesis testing. 


\section{Discussion}

There are neither definite OSH objectives nor belief in the Palestinian OSH system. What is more noticeable is the low OSH awareness. This poor awareness is not limited to one category; on the contrary, it is a severe societal problem. However, this can be considered an international problem, as Jedynska et al. clarified in their report to the European Agency for Safety and Health at Work (EU-OSHA) [66].

The kernel of an effective safety system is a perfectly designed and planned system, providing that raising safety awareness is a priority, developing safety strategies is a must, and the existence of safety requirements and tools is a fact supported by every possible affecting safety stakeholder (Figure 24). Nevertheless, this kernel cannot be formed or shaped unless there is a severe involvement, commitment, responsibility, and cooperation envelope created between every involved safety stakeholder, from each senior official to the most junior employee [33]. Finally, a commitment envelope will never be efficient without being guided by the law and regulations developed and supervised by the main safety officials (MoL, CD), as approved in case correlation (1). This case of correlation had enforced the importance of the OSH strategies and OSH requirements tools for more safe workplaces. Moreover, case correlation (2) promoted the reality of the different $\mathrm{OSH}$ stakeholders' negative attitude towards the OSH issues, assuring the absence of external investigations, awareness activities, practical cooperation, and real desire to understand the OSH fundamentals and recognition the $\mathrm{OSH}$ problem. Yanar et al. proved in their study that the supportive investigation in the workplace besides supervisors could play an essential role in creating a safe work environment and reducing the risk of injury among workers [24]. On the other hand, case correlation (3) reflected the consequences of the lack of OSH awareness, the employees' reckless attitude, and the employee's stability. Moreover, the non-existent correlations that appeared in the case correlation (4) between the primary and periodic medical examinations mainly originate from the failure to conduct these examinations as one of the Labor Law (PLL) violations. Other significant factors that affect the OSH status in Palestine were the law, government, and the resistance to change. Despite all the strenuous efforts and hard work exerted by the MoL in improving the Palestinian $\mathrm{OSH}$ reality, real tangible deficiencies existed concerning OSH law enforcement policies and methodologies.

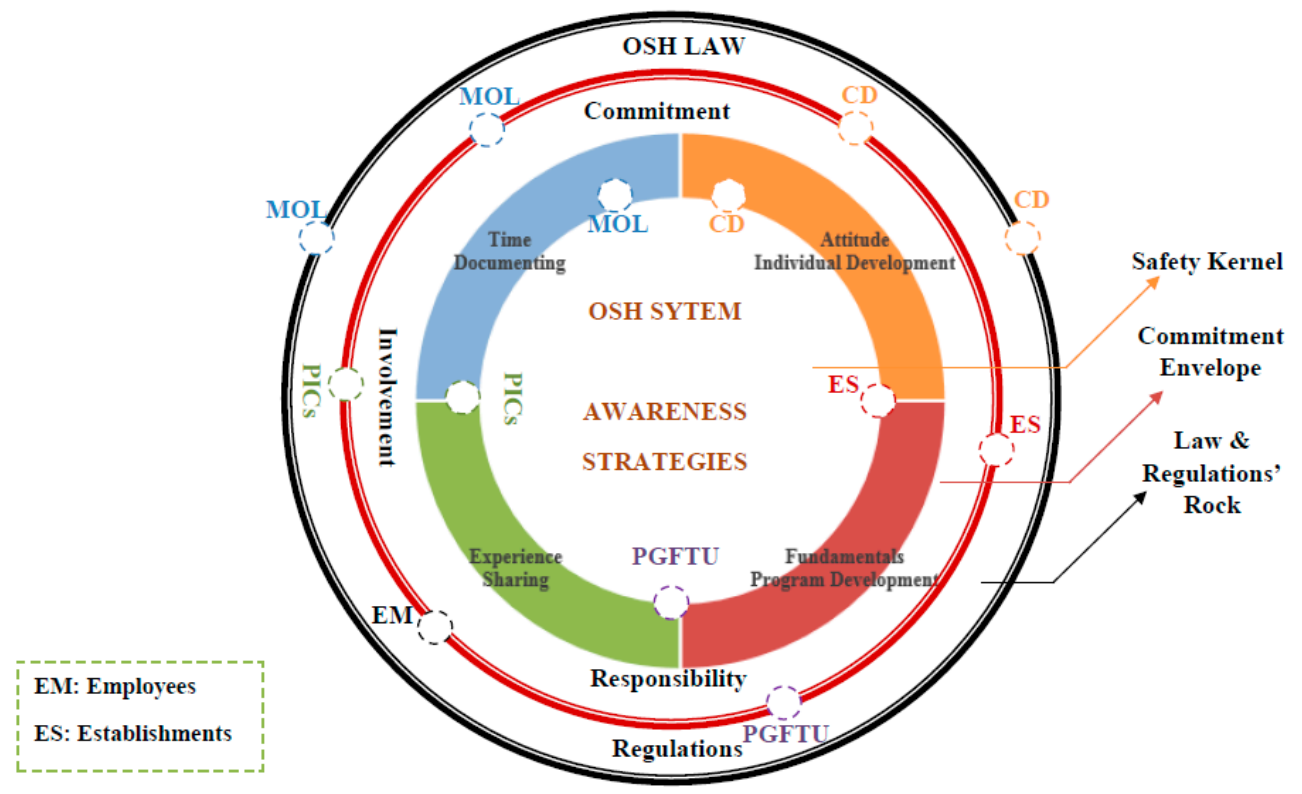

Figure 24. The layers and responsibilities in the safety system.

To overcome OSH's previous issues in Palestine, a conceptual OSH framework has been developed (Figures 25 and 26). Countries worldwide have recognized the necessity of 
developing different strategies, systems, and frameworks to mitigate the occurrences of occupational accidents [33,67-70]. Based on this research and consultation with stakeholders, the outstanding framework was divided into four main phases. The first phase (government phase) is related to OSH governmental commitment and national support. This phase represents the charging and stimulation step for the leading interested authorities toward a practical OSH project. At the same time, it keeps supporting the national industries and their products to give their best. The last step to ensure promoting industries and backing authorities is the needed financial support.

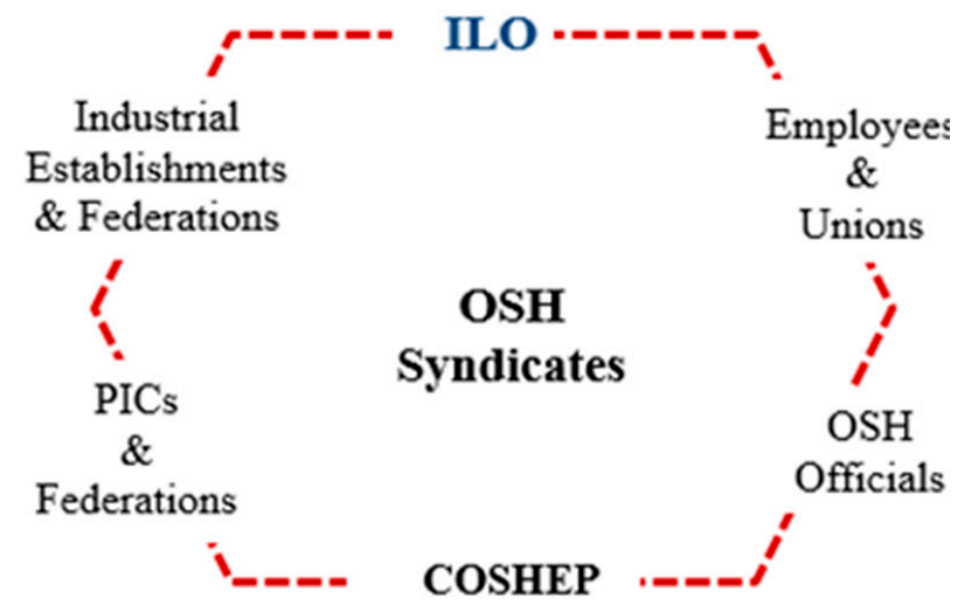

Figure 25. The structure of the proposed OSH syndicates, where: COSHEP = The Palestinian National Center of Occupational Safety, Health, and Environmental Protection, PICs = Palestinian Insurance Companies, ILO = International Labor Organization.

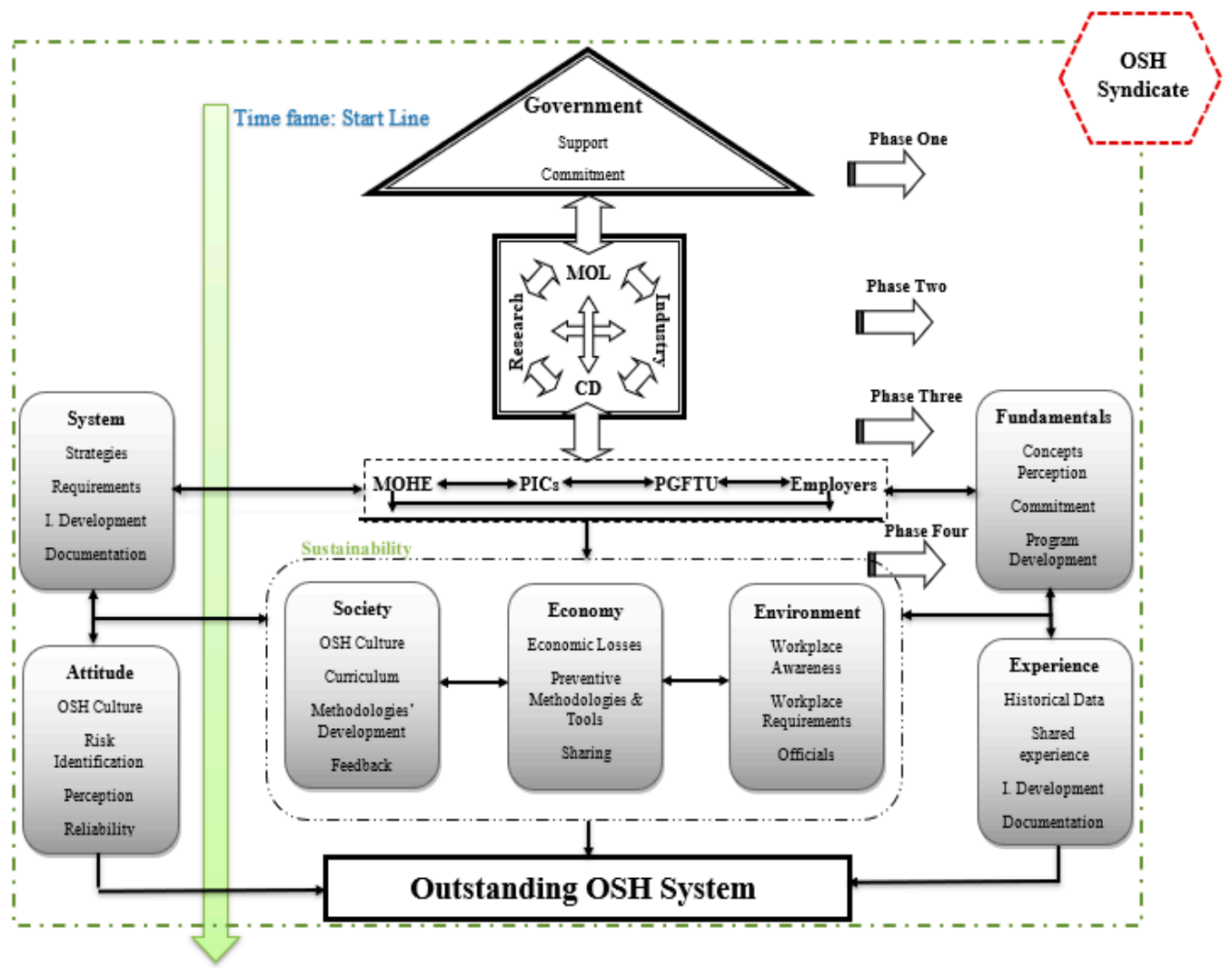

Figure 26. OSH outstanding conceptual framework. 
In the second phase, the entities in the officials' phase derive the financial, moral, and national support from phase one to promote their commitment, responsibility, involvement, coordination, and indeed feedback and documentation toward the government, the project, the stakeholders and employees, and the society. This phase witnesses the coordination, planning, individuals' development, and cooperation with the industrial sectors. For the sake of better results, plans, preparations, and research should be promoted in this phase and the next phases.

The third phase is the participation phase, where each stakeholder starts to mark and contribute to the project. This phase's start is the awareness stage, developing the perception toward the OSH issues, training courses, promotions to identify the workplace hazards, and occupational accidents and diseases, in addition to strategic planning, building an information base, reorganizing the establishments' systems, determining OSH requirements, promoting positive attitudes, strengthening responsibilities and involvement, and offering motivational incentives for stakeholders, employees' cooperation, and feedback.

The last phase is the program development phase, in which the system will be developed, tested, evaluated, and operated to ensure sustainable development. Each stage will be accompanied by revisions, feedback from each input, monitoring for outputs, and documentation for all observations, findings, strengths and weaknesses, failure, and success.

These phases' success depends on many factors: the continuous work, joint efforts, and interrelated activities, where all are to be conducted and executed within a thoughtful timeframe. Besides, a well-designed action plan that starts with the government's belief and commitment and lasts as long as a real outstanding OSH framework is prioritized. Moreover, it is crucial to take into consideration all measures and procedures that are strongly needed to ensure:

- Successful application and enforcement of all the framework phases.

- Rigorous monitoring and following up on the framework development process away from any possible work obstacles that may result from issues like corruption, disruption, procrastination, indifference, or even any intentional and unintentional errors.

A qualified in-charge supervisory body was included in the framework's structure and assumed the primary responsibility of overseeing and advocating the OSH framework's development and its technical, financial, and temporal requirements. Figure 25 illustrates the structure of the proposed OSH syndicates and Figure 26 represents the OSH outstanding conceptual framework for the Palestinian industrial sectors.

Author Contributions: H.S.T.: literature search, figures, data collection, data analysis, data interpretation, and writing —original draft; A.E.-H.: Investigation, conceptualization, project administration, methodology, supervision, and validation, writing-review and editing; A.R.H.: submission of the manuscript, validation, writing-review and editing; H.A.J.: visualization, writing final draftreview and editing. All authors have read and agreed to the published version of the manuscript.

Funding: This research received no external funding.

Institutional Review Board Statement: Not applicable.

Informed Consent Statement: Not applicable.

Data Availability Statement: The data presented in this study are available on request from the corresponding author. The data will be publicly available in a later time and can be accessed through https://scholar.najah.edu/.

Acknowledgments: The authors are thankful for all people who were part of this study.

Conflicts of Interest: The authors of the article confirm that there is no conflict of interest in the submitted article.

Appendix A. OSH Correlations

Case Correlation (1) Hypotheses: 
Hypothesis A1 (H1). There is a correlation between the type of the industrial sector and the number of occurring occupational accidents.

Hypothesis A2 (H2). There is a correlation between the existence of the OSH requirements and the number of occurring occupational accidents.

Hypothesis A3 (H3). There is a correlation between providing OSH training courses and the number of occurring occupational accidents.

Hypothesis A4 (H4). There is a correlation between the number of lost working days/hours and the number of occurring occupational accidents.

Hypothesis A5 (H5). There is a correlation between the employees' commitment follow-up and the number of occurring occupational accidents.

Hypothesis A6 (H6). There is a correlation between developing OSH strategies and the number of occurring occupational accidents.

Hypothesis A7 (H7). There is a correlation between providing motivational incentives and the number of occurring occupational accidents.

Hypothesis A8 (H8). There is a correlation between the type of the industrial sector and the number of occupational injuries.

Hypothesis A9 (H9). There is a correlation between the existence of the OSH requirements and the number of occupational injuries.

Hypothesis A10 (H10). There is a correlation between providing OSH training courses and the number of occupational injuries.

Hypothesis A11 (H11). There is a correlation between the number of lost working days/hours and the number of occupational injuries.

Hypothesis A12 (H12). There is a correlation between the employees' commitment follow-up and the number of occupational injuries.

Hypothesis A13 (H13). There is a correlation between developing OSH strategies and the number of occupational injuries.

Hypothesis A14 (H14). There is a correlation between providing motivational incentives and the number of occupational injuries.

Hypothesis A15 (H15). There is a correlation between the type of the industrial sector and the number of occurrences of occupational diseases.

Hypothesis A16 (H16). There is a correlation between the existence of the OSH requirements and the number of occurrences of occupational diseases.

Hypothesis A17 (H17). There is a correlation between providing OSH training courses and the number of occurrences of occupational diseases.

Hypothesis A18 (H18). There is a correlation between the number of lost working days/hours and the number of occurrences of occupational diseases. 
Hypothesis A19 (H19). There is a correlation between the employees' commitment follow-up and the number of occurrences of occupational diseases.

Hypothesis A20 (H20). There is a correlation between developing OSH strategies and the number of occurrences of occupational diseases.

Hypothesis A21 (H21). There is a correlation between providing motivational incentives and the number of occurrences of occupational diseases.

\section{Case Correlation (2) Hypotheses:}

Hypothesis B1 (H1). There is a correlation between the nature of the industrial sector and exposure to risk.

Hypothesis B2 (H2). There is a correlation between the nature of the industrial sector and providing the $\mathrm{OSH}$ requirements.

Hypothesis B3 (H3). There is a correlation between the nature of the industrial sector and the number of insured employees.

Hypothesis B4 (H4). There is a correlation between the nature of the industrial sector and the number of lost working days/hours.

Hypothesis B5 (H5). There is a correlation between the nature of the industrial sector and the employees' follow-up.

Hypothesis B6 (H6). There is a correlation between the nature of the industrial sector and the motivational incentives.

Hypothesis B7 (H7). There is a correlation between the nature of the industrial sector and the number of external investigation's time.

Hypothesis B8 (H8). There is a correlation between the nature of the industrial sector and developing OSH strategies.

Hypothesis B9 (H9). There is a correlation between the nature of the industrial sector and external cooperation.

Hypothesis B10 (H10). There is a correlation between the nature of the industrial sector and offering OSH training courses.

\section{Case Correlation (3) Hypotheses:}

Hypothesis C1 (H1). There is a correlation between the type of the employee's injuries and his age.

Hypothesis C2 (H2). There is a correlation between the existence of the employee's injuries and his qualification.

Hypothesis C3 (H3). There is a correlation between the employee's injuries and the industrial sector.

Hypothesis C4 (H4). There is a correlation between the employee's injuries and his experience.

Hypothesis C5 (H5). There is a correlation between the employee's injuries and his contract type. 
Hypothesis C6 (H6). There is a correlation between the employee's injuries and working hours.

Hypothesis C7 (H7). There is a correlation between the employee's injuries and working days.

Hypothesis C8 (H8). There is a correlation between the employee's injuries and risk exposure.

Hypothesis C9 (H9). There is a correlation between the employee's injuries and having OSH tools.

Hypothesis C10 (H10). There is a correlation between the employee's injuries and get OSH training courses.

Hypothesis C11 (H11). There is a correlation between the employee's injuries and establishments' incentives.

Hypothesis $\mathrm{C} 12$ (H12). There is a correlation between the type of the employee's diseases and his age.

Hypothesis C13 (H13). There is a correlation between the existence of the employee's diseases and his qualification.

Hypothesis C14 (H14). There is a correlation between the employee's diseases and the industrial sector.

Hypothesis C15 (H15). There is a correlation between the employee's diseases and his experience.

Hypothesis C16 (H16). There is a correlation between the employee's diseases and his contract type.

Hypothesis C17 (H17). There is a correlation between the employee's diseases and working hours.

Hypothesis C18 (H18). There is a correlation between the employee's diseases and working days.

Hypothesis C19 (H19). There is a correlation between the employee's diseases and exposure to risk.

Hypothesis C20 (H20). There is a correlation between the employee's diseases and having OSH tools.

Hypothesis C21 (H21). There is a correlation between the employee's diseases and getting OSH training courses.

Hypothesis C22 (H22). There is a correlation between the employee's diseases and establishments' incentives.

\section{Case Correlation (4) Hypotheses:}

Hypothesis D1 (H1). There is a correlation between primary medical examination and occupational diseases/workplace

Hypothesis D2 (H2). There is a correlation between periodic medical examinations and occupational diseases workplace

Hypothesis D3 (H3). There is a correlation between primary medical examination and occupational diseases employees

Hypothesis D4 (H4). There is a correlation between periodic medical examinations and occupational diseases employees 


\section{References}

1. Fidanc1, İ.; Ozturk, O. General Overview on Occupational Health and Safety and Occupational Disease Subjects. J. Family Med. Health Care 2015, 1, 16-20. [CrossRef]

2. Takala, J.; Hämäläinen, P.; Nenonen, N.; Takahashi, K.; Chimed-Ochir, O.; Rantanen, J. Comparative Analysis of the Burden of Injury and Illness at Work in Selected Countries and Regions. Cent. Eur. J. Occup. Environ. Med. 2017, $23,6-31$.

3. Rantenen, J. Research challenges arising from changes in work life. Scand. J. Work Environ. Health 1999, 25, 473-483. [CrossRef] [PubMed]

4. Peckham, T.K.; Baker, M.G.; Camp, J.E.; Kaufman, J.D.; Seixas, N.S. Creating future for occupational health. Ann. Work Expo. Health 2017, 61, 3-15.

5. Rommel, A.; Varnaccia, G.; Lahmann, N.; Kottner, J.; Kroll, L.E. Occupational Injuries in Germany: Population-Wide National Survey Data Emphasize the Importance of Work-Related Factors. PLoS ONE 2016, 11, e0148798. [CrossRef]

6. Benach, J.; Vives, A.; Amable, M.; Vanroele, C.; Tarafa, G.; Muntaner, C. Precarious employment: Understanding an emerging social determinant of health. Ann. Rev. Public Health 2014, 35, 329-353. [CrossRef]

7. Chen, P.Y.; Cooper, G.L. (Eds.) Work and well-being. In Well-Being: A Complete Reference Guide; John Wiley and Sons: West Sussex, UK, 2017; Volume 3.

8. Hämäläinen, P. The Effect of Competitiveness on Occupational Safety. In Proceedings of the 2007 IEEE, Proceedings of theInternational Conference on Industrial Engineering and Engineering Management, Singapore, 2-4 December 2007. [CrossRef]

9. Harrison, J.; Dawson, L. Occupational health: Meeting the challenges of the next 20 years. Saf. Health Work 2016, 7, 143-149. [CrossRef]

10. Grzebieta, R.H. Welcome to Safety-A New Open Access Journal Helping Shape a Safer World. Safety 2015, 1, 1-6. [CrossRef]

11. Watterson, A. Occupational Safety and Related Impacts on Health and the Environment. Int. J. Environ. Res. Public Health 2017, 13, 988. [CrossRef]

12. Wang, B.; Wu, C.; Huang, L.; Zhang, L.; Kang, L.; Gao, K. Prevention and control of major accidents (MAs) and particularly serious accidents (PSAs) in the industrial domain in China: Current status, recent efforts and future prospects. Process Saf. Environ. Prot. 2018, 117, 254-266. [CrossRef]

13. Yang, Y.; Reniers, G.; Chen, G.; Goerlandt, F. A bibliometric review of laboratory safety in universities. Saf. Sci. 2019, 120, 14-24. [CrossRef]

14. McLellan, R.K. Work, Health, And Worker Well-Being: Roles and Opportunities for Employers. Health Aff. 2017, 36, 206-213. [CrossRef] [PubMed]

15. Safety and Health Add Value. Available online: https://www.osha.gov/Publications/safety-health-addvalue.html (accessed on 12 August 2017).

16. ILO. Plan Safe, Plan Healthy: Guidelines for Developing National Programmes on Occupational Safety and Health; International Labor Organization: Geneva, Switzerland, 2013.

17. Cagno, E.; Micheli, G.J.L.; Perotti, S. Identification of OHS-related factors and interactions among those and OHS performances in SMEs. Saf. Sci. 2011, 49, 216-225. [CrossRef]

18. Dekker, S.; Cilliers, P.; Hofmeyr, J.H. The complexity of failure: Implications of complexity theory for safety investigations. Saf. Sci. 2011, 49, 939-945. [CrossRef]

19. O'Reilly, D.; Rosato, M. Worked to death? A census-based longitudinal study of the relationship between the numbers of hours spent working and mortality risk. Int. J. Epidemiol. 2013, 42, 1820-1830. [CrossRef] [PubMed]

20. Karasek, R.; Theorell, T. Healthy Work: Stress, Productivity, and the Reconstruction of Working Life; Basic Books: New York, NY, USA, 1990.

21. Aas, A. The human factors assessment and classification system (HFACS) for the oil \& gas industry. In Proceedings of the International Petroleum Technology Conference, Kuala Lumpur, Malaysia, 3-5 December 2008.

22. Peters, G.A.; Peters, B.J. Human Error: Causes and Control; CRC/Taylor \& Francis: Boca Raton, FL, USA, 2006.

23. Verma, S.; Chaudhari, S. Safety of Workers in Indian Mines: Study, Analysis, and Prediction. Saf. Health Work 2017, 8, 267-275. [CrossRef]

24. Yanar, B.; Lay, M.; Smith, P. The Interplay Between Supervisor Safety Support and Occupational Health and Safety Vulnerability on Work Injury. Saf. Health Work 2019, 10, 172-179. [CrossRef]

25. Zaki, G.R.; El-Marakby, F.A.; El-Nor, Y.H.D.; Nofal, F.H.; Zakaria, A.M. Occupational safety of different industrial sectors in Khartoum State, Sudan. Part 1: Safety performance evaluation. J. Egypt. Public Health Assoc. 2012, 87, 131-136. [CrossRef]

26. Habib, R.R. Overview of the Occupational Safety \& Health Situation in the Arab Region; International Labour Organization: Geneva, Switzerland.

27. Zekri, M.K. Construction Safety and Health Performance in Dubai. Master's Thesis, Heriot Watt University, Dubai, United Arab Emirates, 2013; pp. 1-84.

28. Staff, T. Work-Related Deaths in Israel among Highest in West, Report Finds. 2016. Timesofisrael.com. Available online: https:// www.timesofisrael.com/work-related-deaths-in-israel-among-highest-in-west-report-finds / (accessed on 10 November 2017).

29. Eldar, S. Israel's construction SECTOR Deadly for Arab Workers. 2017. Al-Monitor. https://www.al-monitor.com/pulse/ originals /2017/09/israel-palestine-construction-workers-accidents-human-rights.html (accessed on 10 November 2017). 
30. Stemn, E. Analysis of Injuries in the Ghanaian Mining Industry and Priority Areas for Research. Saf. Health Work 2019, 10, 151-165. [CrossRef]

31. Al-Thani, H.; El-Menyar, A.; Consunji, R.; Mekkodathil, A.; Peralta, R.; Allen, K.A.; Hyder, A.A. Epidemiology of occupational injuries by nationality in Qatar: Evidence for focused occupational safety programmes. Injury 2015, 46, 1806-1813. [CrossRef]

32. Government of Qatar. Qatar Labor Force Statistics. In Qatar Open Data Portal; Government of Qatar: Doha, Qatar, 2019.

33. Consunji, R.; Mehmood, A.; Hirani, N.; El-Menyar, A.; Abeid, A.; Hyder, A.; Peralta, R. Occupational Safety andWork-Related Injury Control Effeorts in Qatar: Lessons Learned from a Rabidly Developing Economy. Int. J. Environ. Res. Public Health 2020, 17, 6906. [CrossRef] [PubMed]

34. GFPTU. Annual Reports of Injuries and Work Accidents; The General Federation of Palestinian Trade Unions: Ramallah, Palestinian, 2016.

35. PICS. Annual Reports of Injuries and Work Accidents; The Palestinian insurance companies: Ramallah, Palestine, 2016.

36. MOL. Annual Report; MOL: Ramallah, Palestine, 2019.

37. Atturk, L.; Abu-Arra, M. Work Injuries and Compensation in Palestine. In Ramallah: Center for Democracy and Workers Rights (DWRC); The Democracy and Workers' Rights Center: Ramallah, Palestine, 2014.

38. NOSHC. National description of the Occupational Safety and Health; National Occupational Safety and Health Committee (NOSHC): Ramallah, Palestine, 2015.

39. The situation of workers of the occupied Arab territories. In International Labour Conference; 106th Session; International Labour Office: Geneva, Switzerland, 2017; pp. 1-54.

40. MoL. Annual Report of Injuries and Work Accidents; Ministry of Labor: Ramallah, Palestinian, 2016.

41. Al Habeel, W.; Aiesh, A. Evaluating Effectiveness of Occupational Safety and Health Measures in the Scientific Laboratories in the Palestinian Universities in Gaza Strip: A Field Study. J. Islam. Univ. Econo. Adm. Stud. 2012, 83-143.

42. Mohammed, B. Relationship of Learning Organization to Promote Occupational Health and Safety in Medical Imaging Departments at Governmental Hospitals_Gaza strip; Gaza Strip: Al-Azhar University-Gaza, Gaza, Palestinian.

43. Abu Zeiter, S. Safety and Occupational Health and Its Role in Human Development and Reducing Unemployment. Available online: http:/ / www.m.ahewar.org/s.asp?aid=596687\&r=0 (accessed on 4 November 2018).

44. Al Moghny, O. The reality of occupational safety and health measures used in the manufacturing sector in the Gaza Strip; Gaza Strip: The Islamic University, Gaza, Palestinian.

45. Salem, S. Occupational Health and Safety in Industrial Establishments in Palestine. Al-Quds Open Univ. Sci. J. 1-44.

46. The Occupied Palestinian Territory: An Employment Diagonestic Study; International Labor Organization (ILO): Geneva, Switzerland, 2018.

47. USAID; PFI. The Current Status of Industrial Sector in Palestine; CARANA; USAID: Ramallah, Palestine, 2009.

48. PSBC. Economic Survey Series, 2015: Basic Results; Standard Bureau of Statistics: Ramallah, Palestinian, 2016.

49. Saunders, M.; Lewis, P.; Thornhill, A. Research Methods for Business Students, 5th ed.; Pearson Education, Inc.: Boston, MA, USA, 2009.

50. Thompson, S. Sampling., 3rd ed.; John Wiley \& Sons, Inc.: New York, NY, USA, 2012.

51. Jain, A.K.; Hausman, R.E. Stratified Multistage Sampling. Encycl. Stat. Sci. 2014. [CrossRef]

52. Gupta, T.; Dubey, S. Field performance evaluation of a newly developed PM2. 5 sampler at IIT Kanpur. Sci. Total. Environ. 2011, 409, 3500-3507. [CrossRef]

53. Braun, V.; Clarke, V. Using thematic analysis in psychology. Qual. Res. Psychol. 2006, 3, 77-101. [CrossRef]

54. Crowl, D.; Louvar, J. Chemical Process Safety: Fundamentals with Applications, 2nd ed.; Prentice Hall PTR: Upper Saddle River, NJ, USA, 2002.

55. Close, B. Analysis of the Safety Perfonnance Measurement System at Company XYZ. Master's Thesis, University of WisconsinStout, Menomonie, WI, USA, 2010.

56. Chacko, N.; Gopinadhan, P. Integrated Safety Management System in a Construction Organization: A Feasibility Study. IRJET 2016, 3, 2759-2763.

57. WSH. Workplace Safety and Health Report 2016. In National Statistics 2016; Workplace Safety and Health Institute (WSH): Singapore, 2016.

58. Venkataraman, N. Safety Performance Factor. JOSE 2008, 14, 327-331. [CrossRef]

59. Aaltonen, M. Occupational injuries in the Finnish furniture industry. Scand. J. Work Environ. Health 1996, 22, 197-203. [CrossRef]

60. Ceylan, H. Analysis of Occupational Accidents According to The Sectors in Turkey. GU J. Sci. 2012, 25, 909-918.

61. Carrillo-Castrillo, J.A.; Guadix, J.; Rubio-Romero, J.C.; Onieva, L. Estimation of the relative risks of musculoskeletal injuries in the Andalusian manufacturing sector. Int. J. Ind. Ergon. 2016, 52, 69-77. [CrossRef]

62. HSA. Summary of Workplace Injury, Illness and Fatality Statistics 2016-2017; The Health and Safety Authority: Dublin, Ireland, 2018.

63. U.S. Bureau of Labour Statistics. Available online: https:/ /www.bls.gov/web/osh/summ1_00.htm (accessed on 22 January 2019).

64. HSE. Health and Safety in Manufacturing in Great Britain, 2014/2015; Health and Safety Executives: London, UK, 2015.

65. Lagerstrom, E.; Magzamen, S.; Kines, P.; Brazile, W.; Rosecrance, J. Determinants of Safety Climate in the Professional Logging Industry. Safety 2019, 5, 35. [CrossRef] 
66. Jedynska, A.; Kuijpers, E.; Van den Berg, C.; Kruizinga, A.; Meima, M.; Spaan, S. Biological Agents and Work-Related Diseases: Results of a Literature Review, Expert Survey and Analysis of Monitoring Systems: European Risk Observatory Literature Review; The European Agency for Safety and Health at Work (EU-OSHA): Luxembourg, 2019. [CrossRef]

67. Makin, A.; Winder, C. A new conceptual framework to improve the application of occupational health and safety management systems. Saf. Sci. 2008, 46, 935-948. [CrossRef]

68. Sarsour, A.; Ayoub, A.; Shahrour, I. Rapid assessment of occupational health and safety measures for personnel handling healthcare waste in the Gaza Strip, Palestine. Int. J. Environ. Health 2014, 7, 156-170. [CrossRef]

69. Kamar, I.; Che Ahmad, A. A Conceptual Framework of Safety and Health in Construction Management. MATEC Web Conf. EDP Sci. 2016, 66, 00107. [CrossRef]

70. Campo, G.; Cegolon, L.; De Merich, D.; Fedeli, U.; Pellicci, M.; Heymann, W.; Mastrangelo, G. The Italian National Surveillance System for Occupational Injuries: Conceptual Framework and Fatal Outcomes, 2002-2016. Int. J. Environ. Res. Public Health 2020, 17, 7631. [CrossRef] 